\title{
DOE/RL/0/830-T62
}

\section{Natural Resource Valuation: A Primer on Concepts and Techniques}

\author{
C.A. Ulibarri \& K.F. Wellman
}

July 1997

Prepared for

the U.S. Department of Energy

under Contract DE-AC06-76RLO 1830

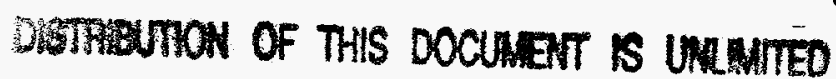

\section{pex}




\section{DISCLAMMER}

Portions of this document may be illegible in electronic image products. Images are produced from the best available original document. 


\section{DISCLAIMER}

This report was prepared as an account of work sponsored by an agency of the United States Government. Neither the United States Government nor any agency thereof, nor any of their employees, make any warranty, express or implied, or assumes any legal liability or responsibility for the accuracy, completeness, or usefulness of any information, apparatus, product, or process disclosed, or represents that its use would not infringe privately owned rights. Reference herein to any specific commercial product, process, or service by trade name, trademark, manufacturer, or otherwise does not necessarily constitute or imply its endorsement, recommendation, or favoring by the United States Government or any agency thereof. The views and opinions of authors expressed herein do not necessarily state or reflect those of the United States Government or any agency thereof. 


\section{Acknowledgments}

The authors wish to thank Drs. Heino Beckert and Andrew Wallo of the U.S. Department of Energy for supporting this research endeavor and Dr. Gordon Bilyard, Thomas Grant, and Thomas Marsh of the Pacific Northwest National Laboratory for helpful comments and suggestions. Additionally, the authors give thanks to Judy Danko, Joan Slavens, and Marlene Hale for editorial and technical assistance in preparing this document.

The authors hold no one but themselves accountable for lapses of judgment and omissions in this effort. 


\section{Executive Summary}

Natural resource valuation has always had a fundamental role in the practice of cost-benefit analysis of health, safety, and environmental issues. Today, this role is becoming all the more apparent in the conduct of natural resource damage assessments (NRDA) and cost-benefit analyses of environmental restoration (ER) and waste management (WM) activities. As such, environmental professionals are more interested in how natural resource values are affected by ER and WM activities. This professional interest extends to the use of NRDA values as measures of liability and legal causes of action under such environmental statues as the Clean Water Act (CWA); the Comprehensive Environmental Response, Compensation, and Liability Act of 1980 (CERCLA, as amended); and the Oil Pollution Act (OPA) of 1990. Also, environmental professionals are paying closer attention to NRDA values in cost-benefit analyses of risk and pollution-abatement standards, and in meeting environmental and safety standards - for instance, the attainment of dose limits as low as is reasonably achievable (ALARA). This handbook reviews natural resource valuation techniques that may be applied to resources at DOE sites within the foregoing contexts.

At the onset, the authors wish to emphasize what this handbook is and what it is not. It is not an effort to provide a comprehensive review of environmental benefit valuation studies. Rather, the selection of case material is an attempt to exemplify where field studies of natural resource values can play an important role in ER and WM activities at federal facilities. For this reason, the discussion is aimed at noneconomists and pays specific attention to the more basic economic principles and techniques that are currently used by leading practitioners in the estimation of natural resource values. Box illustrations of 
case studies are used to highlight the application of these methods by a number of leading practitioners. The discussion does not recommend the use of any one method over another, nor does it analyze the correctness of any one application. Instead, the aim is to provide an overview of the applicability of the various methods to particular situations that may be relevant to ER and WM activities at federal facilities.

Federal agencies and environmental contractors are in the process of responding to changing trends and protocols in assessing natural resource damages. Specifically, these include assessing "nonuse values" in the evaluation of restoration alternatives, estimating compensable values for damages sustained by natural and environmental resources, and complying with risk and performance-based environmental standards. The new emphasis given to nonuse values as components of the natural resource damage assessment process will no doubt motivate many state-of-the-art applications of resource valuation techniques. Environmental professionals recognize the stakes of incorporating these unconventional values in resource damage assessments and the role of state and federal governments in seeking damages from potentially responsible parties. Accordingly, the interest of the U.S. Department of Energy (DOE) in the applicability of resource valuation techniques is well-founded.

In response to this interest, the authors provide an objective overview of resource valuation techniques and describe their potential role in environmental restoration/waste management (ER/WM) activities at federal facilities. With environmental professionals in mind, the objectives of this work are to increase awareness of the viability of resource valuation techniques; to explain the potential application of NRDA values; and to describe, where appropriate, the potential difficulties and uncertainties associated with NRDA valuation techniques. This handbook considers five general classes of valuation techniques: 1) market-based techniques, which rely on historical information on market prices and transactions to determine resource values; 2) nonmarket techniques that rely on indirect estimates of 
resource values; 3) nonmarket techniques that are based on direct estimates of resource values; 4) cross-cutting valuation techniques, which combine elements of one or more of these methods; and 5) ecological valuation techniques used in the emerging field of ecological economics. Given the state of the art in applying these methods and the number and variety of successful applications to date, each one of these valuation methods is worthy of consideration at DOE sites.

The various valuation techniques under consideration are described by highlighting their applicability in environmental management and regulation. As to coverage and level of technical detail, efforts are made to address the advantages and limitations of the techniques using illustrative case studies of natural resources as defined under CERCLA; that is, land, water, fish, wildlife, biota, air, groundwater, and drinking water supplies. The handbook also addresses key unresolved issues in the application of valuation techniques generally, including discounting future values, incorporating environmental equity concerns, and concerns over the uncertainties in the measurement of natural resource values and environmental risk. These topics are discussed individually, recognizing that economic theory offers no precise quantitative adjustment for handling any one issue. A bibliography of the natural resource valuation literature is provided, as are glossaries of relevant terms and environmental statutes. 


\section{Contents}

Acknowledgments $\ldots \ldots \ldots \ldots \ldots \ldots \ldots \ldots \ldots \ldots \ldots$ iii

Executive Summary $\ldots \ldots \ldots \ldots \ldots \ldots \ldots \ldots \ldots$

Introduction $\ldots \ldots \ldots \ldots \ldots \ldots \ldots \ldots \ldots \ldots \ldots \ldots \ldots$

Background $\ldots \ldots \ldots \ldots \ldots \ldots \ldots \ldots \ldots \ldots \ldots \ldots$

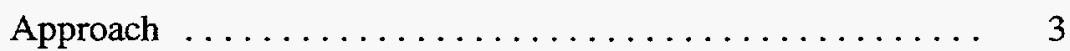

Natural Resource Valuation Techniques $\ldots \ldots \ldots \ldots \ldots$. 5

Market-Based Techniques $\ldots \ldots \ldots \ldots \ldots \ldots \ldots \ldots \ldots$

Market Price Approach . . . . . . . . . . . . 7

Appraisal Method $\ldots \ldots \ldots \ldots \ldots \ldots \ldots \ldots \ldots \ldots \ldots$

Resource Replacement Cost Method ........... 13

Nonmarket Valuation: Indirect Techniques ......... 14

Travel Cost Model $\ldots \ldots \ldots \ldots \ldots \ldots \ldots \ldots \ldots \ldots$

Random Utility Models $\ldots \ldots \ldots \ldots \ldots \ldots \ldots \ldots . . \ldots$

Hedonic Price Method - Amenity Value ........... 19

Hedonic Price Method - Value of Life ........... 20 
Factor Income Method $\ldots \ldots \ldots \ldots \ldots \ldots \ldots \ldots . \ldots \ldots$

Nonmarket Valuation: Contingent Valuation $\ldots \ldots \ldots \ldots 25$

Cross-Cutting Methods $\ldots \ldots \ldots \ldots \ldots \ldots \ldots \ldots \ldots, 28$

Benefit Transfer $\ldots \ldots \ldots \ldots \ldots \ldots \ldots \ldots \ldots \ldots \ldots \ldots \ldots \ldots \ldots$

Unit Day Value Method $\ldots \ldots \ldots \ldots \ldots \ldots \ldots \ldots \ldots .30$

Ecological Valuation $\ldots \ldots \ldots \ldots \ldots \ldots \ldots \ldots \ldots \ldots, 32$

Ecological Economics $\ldots \ldots \ldots \ldots \ldots \ldots \ldots \ldots \ldots .33$

Gross Primary Energy Valuation $\ldots \ldots \ldots \ldots \ldots \ldots .34$

Ecological Resource Valuation $\ldots \ldots \ldots \ldots \ldots \ldots \ldots .34$

Unresolved Issues $\ldots \ldots \ldots \ldots \ldots \ldots \ldots \ldots \ldots \ldots \ldots \ldots$

Discounting and Time Preference $\ldots \ldots \ldots \ldots \ldots \ldots \ldots, 37$

Equity and Fairness $\ldots \ldots \ldots \ldots \ldots \ldots \ldots \ldots \ldots, 41$

Risk and Uncertainty $\ldots \ldots \ldots \ldots \ldots \ldots \ldots \ldots \ldots \ldots \ldots \ldots$

Margin of Error: An Order of Magnitude? . . . . . . . 47

Conclusions $\ldots \ldots \ldots \ldots \ldots \ldots \ldots \ldots \ldots \ldots \ldots \ldots \ldots \ldots \ldots \ldots \ldots \ldots$

Bibliography $\ldots \ldots \ldots \ldots \ldots \ldots \ldots \ldots \ldots \ldots \ldots \ldots \ldots \ldots$

Appendix A - Economics Glossary . . . . . . . . . A -1

Appendix B - Regulatory Glossary . . . . . . . . . B-1 


\section{Introduction}

The Comprehensive Environmental Response, Compensation, and Liability Act (CERCLA) authorizes the President of the United States to designate federal officials who would act as trustees of publicly owned natural resources. In the case of the U.S. Department of Energy (DOE), Executive Order 12580 recognizes the Secretary of Energy as the primary Federal Trustee for natural resources located on, over, or under land administered by DOE. Consequently, as DOE proceeds with the cleanup of its sites across the nation under CERCLA and other environmental protection statutes, field offices must be sensitive to the impacts of environmental restoration (ER) and waste management (WM) activities on natural resources. Environmental professionals realize many of their decisions will affect the use of natural resources now and in the future and are aware of the increase in public concern over potential injuries sustained by natural resources. They are paying closer attention to natural resource values in cost-benefit analyses of risk and pollution-abatement standards, and in meeting environmental safety standards, for instance, the attainment of dose limits as low as reasonably achievable (ALARA). The purpose of this handbook is to describe the key concepts and techniques that are used in the valuation of natural resources and their application to resources at DOE facilities.

\section{Background}

Interest in natural resource valuation has been heightened by recent regulatory developments in resource damage assessments under CERCLA. Damage assessments are conducted to determine the extent of injury to natural resources and to calculate compensatory monetary damages. The new protocols in the damage assessment process are 
helping delineate appropriate measures of compensation for injury to natural resources. In addition, they have also broken new ground by focusing on injuries that may remain after site restoration activities are completed. These developments have increased the role of natural resource valuation techniques in determining the magnitude of monetary damage claims under CERCLA (as amended).

The original regulations for conducting resource damage assessments prescribed that public trustees of natural resources use the lesser of restoration costs or foregone use values as the basis of measuring natural resource and environmental damages. Nonuse values were considered only as a last resort, when no use values could be measured. These conventions were rearranged by judicial decision in State of Ohio v. the U.S. Department of Interior (1989), which broadened the scope of nonuse values to situations in which these values can be reliably measured. The new protocols include the recognition of nonuse values in the evaluation of restoration alternatives, compensable values, and preliminary estimates of damage sustained by natural and environmental resources.

Analysts recognize the increased concern for nonuse values as a component of the natural resource damage assessments (NRDA) process and the stakes of incorporating nonuse values in damage assessments. Meanwhile, the greater public interest in preserving natural and environmental resources (environmental ethics) has led to new applications of resource valuation methods that are increasingly sensitive to nonuse values. Examples include the growing interest in preserving natural resources for present and future generations through the American Indian Religious Freedom Act, the National Historic Preservation Act, and the Archaeological Resources Protection Act.

These social and cultural movements suggest increased opportunities for stakeholders to reflect their value for natural resources in public decision-making and the resolution of environmental conflicts. 
In complying with environmental statutes, DOE's stewardship role in protecting natural resources has become a public focal point. As the DOE recognizes the public interest in its environmental clean-up activities, environmental contractors must remain responsive to the extensive set of rules that implement major federal environmental statutes, such as the National Environmental Policy Act, the Clean Air Act, and the Clean Water Act. In addition, DOE staff and contractors involved in environmental restoration activities must remain responsive to other administrative rules and actions, such as Executive Order 11988 (Floodplain Management), Executive Order 11990 (Protection of Wetlands), and the Endangered Species Act. In complying with these and other policy initiatives, DOE and its environmental contractors will have a significant impact on the monetary value of natural and environmental resources. Ultimately, the monetary value of such resources may reflect on how well DOE meets its trustee responsibilities as a steward of natural resources as it remediates and restores sites and decontaminates facilities.

\section{Approach}

This handbook provides an overview of current natural resource valuation methods, focusing on their applicability in the field operations of federal agencies. Unfortunately, much of what is written on resource valuation methodology stems from a technical literature which field professionals may find difficult to apply. The authors attempt to bridge this gap by targeting environmental managers and policy makers, the stewards of natural resources. No assumptions are made about the readers' familiarity with the conceptual underpinnings of economic valuation methods or how applicable these valuation tools are in the preparation of regulatory compliance documents.

By interpreting valuation methods in an applied context, the authors intend to provide noneconomists with greater awareness of the techniques that are used and the current issues, trends, and decisions that 


\section{4 / Introduction}

affect their use. Examples of issues and concerns that DOE field offices could face in the near future include the following:

- valuation of cost-benefits in health, safety, and environmental risk standards

- valuation of ecological resources, such as wetlands or arid lands

- new approaches in resource valuation or the NRDA process

- growing awareness of stakeholders over health, safety, and environmental risks.

By explaining these valuation questions, the authors seek to give the reader a better feel for the use of economic valuation tools in qualitative and quantitative assessments of natural resource values. Here, an effort is made to review natural resource valuation techniques from a federal agency perspective. Through its field offices, DOE is the steward of a wide array of natural resources, encompassing large tracts of undeveloped lands, extensive watersheds and forests, and diverse wildlife.

Although the focus of this handbook is on conventional economic valuation methods, it is readily acknowledged that conventional economics offers only one approach to natural resource valuation. Alternative disciplinary perspectives cannot be ignored. Therefore, the authors include ecological economics as an emerging discipline. Overall, the methods and case studies considered here were chosen by the authors at the Pacific Northwest National Laboratory ${ }^{(a)}$ and at the Battelle, Seattle Research Center.

(a) Pacific Northwest National Laboratory is operated for the U.S. Department of Energy by Battelle under Contract DE-AC06-76RLO 1830. 


\section{Natural Resource Valuation Techniques}

This section describes methods used in the valuation of natural and environmental resources and resource services. Examples are used to illustrate their potential applicability in a variety of situations, such as land valuation upon completion of restoration activities or water valuation following the prevention of toxic discharges. The key is to estimate the demand for the beneficial uses or services that natural resources provide individuals and communities. Where markets for the resource or its services exist, assessment is relatively straightforward. An example would be a local real estate market. Observations on the number and value of transactions provide information about the people's willingness to pay for land and the quantity of land changing hands. These market data provide a means through which to deduce the market demand curve and the actual payments made during a given period of time.

When a market such as this exists, it is relatively easy to apply marketbased techniques to measure value. These techniques include the market price approach, the appraisal method, and the replacement cost method. Otherwise, when market data is not available, valuation requires the use of nonmarket techniques to derive information on individual willingness to pay. The most widely recognized nonmarket techniques include the travel cost method, the hedonic price method, and the contingent valuation method. Also, cross-cutting methods have been used as a way to combine market-based and nonmarket methods of valuation, such as the benefit-transfer method or the unit-day value method. Finally, other recent approaches have focused on the valuation of ecological functions. Table 1 provides an overview of these 
Table 1 Valuation Techniques, Benefit Types, and Selected Case Studies

\begin{tabular}{|c|c|c|}
\hline $\begin{array}{c}\text { Economic Valuation } \\
\text { Techniques }\end{array}$ & Types of Benetits & Selected Case Studies \\
\hline Market price approach & Recreational/existence value & Loomis and Anderson (1992) \\
\hline Appraisal methods & "Fair market values" of land & Scott et al. (1997) \\
\hline Resource replacement cost & Groundwater resource values & Shechter (1985) \\
\hline Travel cost method & Recreational/existence values & Scott et al. (1997) \\
\hline Random utility models & Recreational/existence values & Morey et al. (1991) \\
\hline Hedonic price method & $\begin{array}{l}\text { Groundwater/land value } \\
\text { Human health/value of life }\end{array}$ & $\begin{array}{l}\text { Kopp and Smith (1992) } \\
\text { Viscusi (1990) }\end{array}$ \\
\hline Factor income approach & Fresh water supply & None considered \\
\hline Contingent valuation method & Use/non-use values & Kopp and Smith (1992) \\
\hline Benefit-transfer method & Air quality/visibility & Ulibarri and Ghosh (1995) \\
\hline Unit-day value method & Recreational value & Loomis and Anderson (1992) \\
\hline Ecological valuation approach & $\begin{array}{l}\text { Gross primary energy value and } \\
\text { intrinsic value }\end{array}$ & $\begin{array}{l}\text { Constanza et al. (1989) and } \\
\text { Scott et al. (1997) }\end{array}$ \\
\hline
\end{tabular}

techniques and the types of benefits that are examined below. Specific consideration is given to each of these valuation techniques with the aid of box illustrations of selected case studies.

The natural resource valuation techniques identified in Table 1 provide a relatively broad picture of the economic thinking that goes into the monetary valuation of natural resources. However, a further point should be made. Despite considerable progress over the last twenty some years, the monetary valuation of natural resources (or environmental commodities) remains in a state of flux. The natural resource valuation techniques considered in this handbook are no exception. Thus, although monetary estimates of natural resource values are given, they should be regarded as approximations - at best, an order-ofmagnitude indication of the actual numbers. Unfortunately, there is 
hardly any research to refer to which has attempted to validate or compare the monetary value estimates identified in this handbook. As such, it is difficult to measure the range of uncertainties that underlie these estimates. For this reason, the authors have not adjusted any of the monetary values for inflation; for to do so would, in the words of Allen Kneese, "confer on them an unfounded degree of accuracy."

\section{Market-Based Techniques}

The pioneers of natural and environmental resource valuation relied on the "law of demand" as a way to measure the market values for natural resources and environmental amenities. While the same is true today, the degree of sophistication in the measurement of these values has increased considerably. Three market-based techniques that have recorded a significant history of natural and environmental resource valuations are described here: the market price approach, the appraisal method, and resource replacement costing.

\section{Market Price Approach}

Demand for natural resources is measured on the assumption that many factors that might influence demand, such as personal income, the prices of related goods and services, and individual tastes and preferences, remain unchanged during the study period. Under these assumptions, the estimated demand curve is a systematic measure of how people value the resource. To illustrate, Figure 1 shows that 20,000 acres of land were sold at a market price of $\$ 1500$ per acre. In the course of these land transactions, $\$ 30.0$ million exchanged hands in the land market, i.e., $20,000 \times \$ 1500$. Had land become increasingly scarce, this scarcity would ultimately be reflected in higher land prices. Either fewer people would purchase the land, or the same people would purchase less land. 
8 /Valuation Techniques

Figure 1 Demand, Supply, and Market Valuation

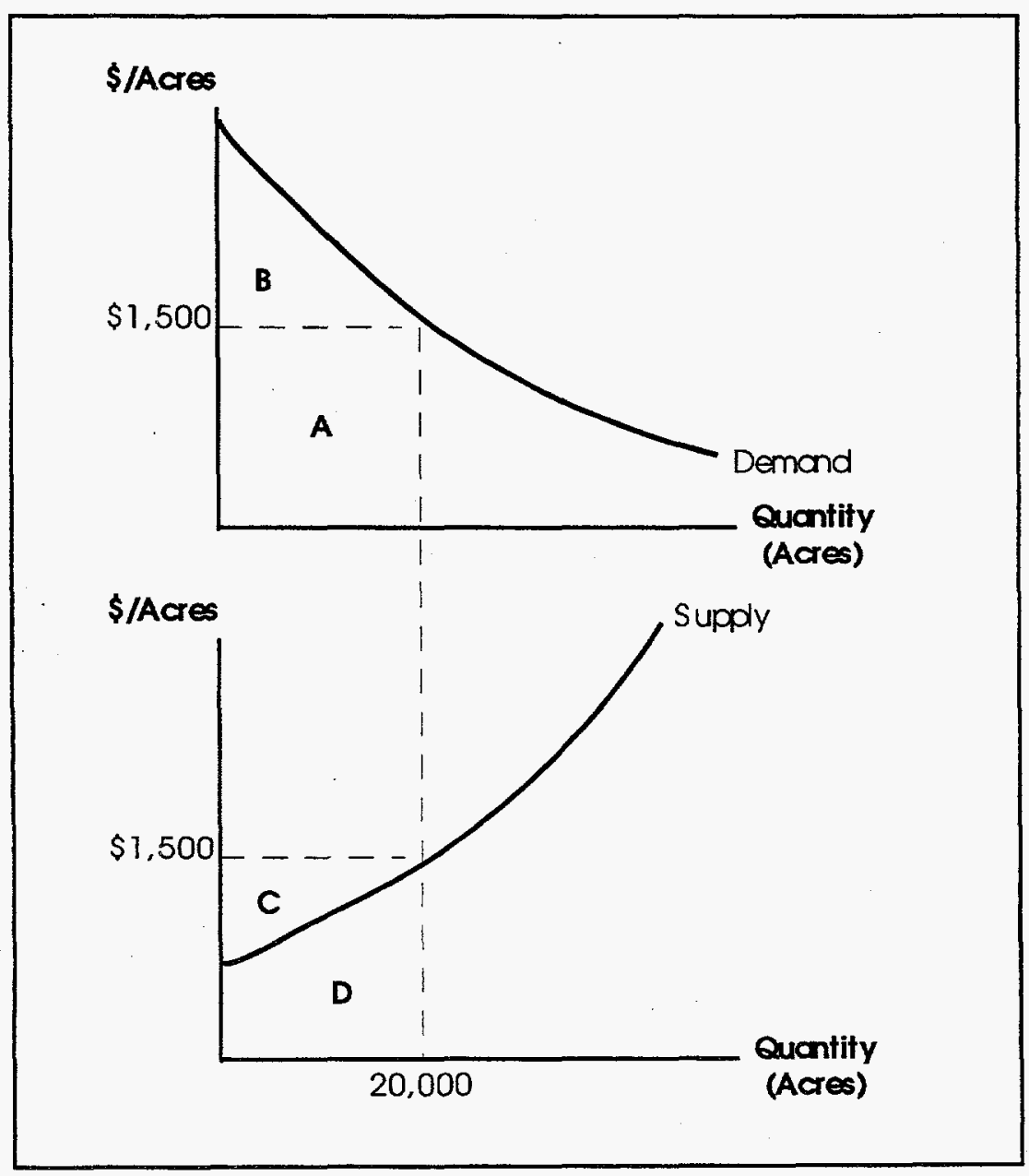


Now, consider the total area beneath the demand curve up to 20,000 acres, as defined by $A+B$. This area measures the value of the resource in terms of the maximum willingness to pay for the 20,000 acres of land. The total willingness to pay for 20,000 acres is calculated by adding up what was actually spent in buying the land, $\mathrm{A}=$ $\$ 30$ million, plus the additional triangular area $B$, which defines consumer surplus. Consumer surplus is the difference between people's maximum willingness to pay for 20,000 acres of land $(A+B)$ and what they actually paid (A). In essence, the area gives a dollar measure of satisfaction that people received from the land, less what they actually pay for it.

As a dollar measure of individual welfare, consumer surplus and expected consumer surplus are satisfactory for most studies, and many analysts have found them to be good empirical approximations of more theoretically desirable measures. Evaluating consumer surplus requires data of market transactions for varying prices and quantities, as well as information on personal income and the prices of related goods and services. People's expenditures on resources would be an inappropriate measure of willingness to pay because it omits the consumer's surplus from the overall valuation.

Producer surplus and economic rent are two other measures of the benefits (or damages) associated with natural resources and resource services. Producer surplus measures monetary gains from the production of natural resources, which is the difference between revenues $(C+D)$ and the economic costs of producing these resources (D). Similarly, economic rent measures monetary gains from using natural resources as factors of production, which is the difference between the actual payments made in using resources and the lowest payment that their owners would have been willing to accept in supplying these resources or resource services. Thus, producer surplus refers to the sellers' gains from trade in the product market, while economic rent measures the sellers' gains from trade in the input market. Accordingly, the use of producer surplus or economic rent in resource 
valuation problems depends on whether the natural resource is considered as a final product or as an input in the production of a final product.

\section{Example 1: Market Price Approach to Measuring Producer Surplus}

In 1987, a truck carrying a hazardous substance called Vitavax 200 (a fungicide) overturned, spilling over 200 gallons of Vitavax 200 into the Little Salmon River in Idaho. The Little Salmon River contains a variety of fish, including steelhead trout. At the time of the spill, most of the steelhead were either wild fish or what was referred to in this case as natural fish (a naturally spawned fish with at least one ancestor being a hatchery fish).

The State of Idaho filed suit in the U.S. District Court of Idaho against the truck owner and the transportation company (Southern Refrigerated Transport) under Section 107 of the Comprehensive Environmental Response, Compensation, and Liability Act; the Idaho Hazardous Materials/Hazardous Waste Transportation Act; and the Idaho Environmental Protection and Health Act. Idaho, which claimed that the fungicide killed over 90 percent of the fish in the Little Salmon River, sought damages for injury to its natural resources (fish), reimbursement for the costs incurred to clean up the spill site and assess the damages, and relevant civil penalties. These injury claims were based on the notion that reduced incomes or rents to resource producers (or trustees) provide a basis for estimating compensable values in natural resource damage assessments.

Loomis and Anderson (1992) on behalf of the plaintiff determined that losses were incurred by the State of Idaho as a producer of recreationally caught steelhead, by anglers for lost recreational use, and by the general public through their existence values. In order to determine the lost value to the State of Idaho of reduced salmon stocks, they used market techniques to determine producer values. Total revenue for the steelhead was identified as the price times quantity of steelhead produced. Loomis and Anderson relied on the American Fisheries Society estimates (1982) of values per steelhead in each size class to arrive at an initial total revenue. This value was adjusted upward to reflect the doubled survival rate of wild and native steelhead that were represented by the fish killed as compared to survival rates of pure hatchery steelhead. However, because the wild steelhead reproduce naturally in the Little Saimon River, there is little direct cost (beyond the opportunity costs of river flows, etc.) to the State of ldaho. Therefore, the entire total revenue was taken as net economic loss or producer surplus foregone to the State of Idaho.

Source: American Fisheries Society. 1982. Monetary Values of Freshwater Fish and Fish-Kill Counting Guidelines, Bethesda, Maryland; and Loomis, J., and Anderson, P. 1992. Idaho v. Southem Refrigerated in Natural Resource Damages: Law and Economics, Ward and Duffield (ed.), John Wiley and Sons, Inc., New York. 
Referring again to Figure 1, producer surplus is shown by the area C, which is bordered by the resource supply curve and the market price of the resource, $P=\$ 1500$. This measure reflects changes in the availability of the natural resource. For example, if the natural resource were damaged, its supply curve would shift leftward and producer surplus would diminish. A similar description could be given to natural resource damages that result in a reduction in economic rent. Here, the damages would be incurred by the owners of the resources. As in the case of measuring the consumer surplus, both producer surplus and economic rent require historical information on the market prices and quantities of natural resources. In addition, the measures of producer surplus and economic rent require information relating to the economic costs of producing and/or supplying the resource to the market.

\section{Appraisal Method}

Appraisal methods are particularly well suited to cases involving natural resources that have been damaged. In the case of land, for example, the appraiser identifies the fair market value for comparable properties in both the uninjured and injured conditions. The fair market value of the resource (land) is roughly defined as the amount a knowledgeable buyer would pay a knowledgeable seller for the resources. This value should reflect, as closely as possible, the price at which the resource would actually sell in the market place at the time of the injury.

The application of appraisal methods would seem to hold particular promise in DOE natural and environmental resource planning and guidance. Appraisal methods for resource valuation work have been found to be reliable under the Department of Interior's and the National Oceanic and Atmospheric Administration's natural resource damage assessment regulations. However, the point to keep in mind is that the method is, in fact, quite dependent on the appraiser's judgment. It may be very difficult to identify comparable sales, particularly for properties that are "comparably" injured. In addition, the types of natural 
resources to which this method can be applied are limited since many natural and environmental resources are not traded in markets. Nevertheless, appraisal methods are applicable to soil and water treatment at federal facilities. Therefore, it is instructive to consider a notable protocol in applying appraisal methods.

At present, the U.S. Department of Interior suggests that land appraisal methods be conducted in accordance with the "Uniform Appraisal Standard for Federal Land Acquisition" (CFR 1991). The Interagency Land Acquisition Conference has developed a hierarchy of data to be used by appraisers. This hierarchy, ranked from most preferred to least preferred, includes prior sales of the same resource, prior sales of an identical resource, and prior sales of "comparable" resources. The Conference notes that an appraiser is likely to use a combination of the three types of data.

\title{
Example 2: Appraisal Method
}

\begin{abstract}
Scott et al. (1997) estimated the "fair market value" associated with shrub-steppe conversions based on sample data from Benton-Franklin Counties of eastern Washington State. The data were obtained from the Benton County Assessor's Office and represent sales transactions in Benton County involving 7700 acres during the 1993-1994 calendar year. The sample was selected to ensure the identification of recent patterns in the regional development of shrub-steppe land. Consequently, the sample contained 17 transactions of property for residential and/or commercial development (urban use) and 31 transactions involving property destined for agricultural development (agricultural use). The authors categorized the sales of predisposed agricultural land according to whether it was irrigated, or whether it would be used as dry pasture land or dry farm land. The sampling of real estate transactions found that shrub steppe for urban development had the highest average value, $\$ 9208$ per acre. Dry pasture land had the lowest average value, $\$ 67$ per acre. Meanwhile, irrigated farm land sold for $\$ 1484$ per acre.
\end{abstract}

Source: Scott, M.J., et al. 1997. "The Valuation of Ecological Resources and Functions." Environmental Management (forthcoming). 


\title{
Resource Replacement Cost Method
}

The costs of replacing natural and environmental resources are sometimes a useful way of approximating resource values under specific conditions. The resource replacement cost method determines damages for natural resources based on the cost to restore, rehabilitate, or replace the resource or resource services without injury to the level of the resource stock or service flow. In instances where the underlying resource is not unique and substitutes are readily available, the application of the replacement cost method is relatively straightforward. The investigator proceeds by gathering a sample of values for the substitutes from primary or secondary source information. Based on this sample of cost information, the analyst then prepares an estimate of the most likely range of expected replacement costs for the underlying resource

\section{Example 3: Resource Replacement Cost Method}

\begin{abstract}
Shechter (1985) applied the replacement cost method at the Price Landfill in New Jersey to obtain cost estimates of altematives to deal with groundwater contamination. Estimates were based on information obtained from the U.S. Environmental Protection Agency (1978) and Environmental Science and Technology (1980). Excluding excavation and reburials, the estimated costs ranged from $\$ 5$ million to $\$ 8$ million (in 1980 dollars) and included containment and management of the plume, along with the performance of water treatment until the aquifer had been purged of noxious substances. If excavation and reburial were undertaken as part of the restoration process, the researchers suggest that the period of plume management and groundwater flow control could be shortened, but that total cost would rise by about $\$ 15$ million to $\$ 18$ million. Other site restoration activities included in their estimation focused on securing alternative sources of water to meet Atlantic City's water demand for the foreseeable future. These included cost estimates for the development of a well field to replace four threatened wells, vanying between $\$ 6.5$ million and $\$ 9.3$ million. The researchers omitted other administrative costs from consideration in applying the method, such as the costs of undertaking various federal, state, and local studies on the landfill problem, and the attendant litigation costs that might be involved. It was believed that these administrative costs had the potential to raise the total cost by another $\$ 1.5$ million.
\end{abstract}

Sources: Shechter, M. 1985. "Economic Aspects in the investigation of Groundwater Contamination Episodes," in Ground Water, Volume 23, Number 2, U.S. Environmental Protection Agency. Guidance Manual for Minimizing Pollution from Waste Disposal Sites, EPA 600/2-78-142, Washington, D.C. Environmental Science and Technology: 1980. Groundwater Strategies, Vol. 14, pp. 1030-35. 
or service. This process may be far more difficult to implement in instances where resources possess unique characteristics. In these cases, little information exists to assemble a sample upon which to estimate the expected value of the underlying resource.

While the replacement cost approach has been used in court settlements for damaged resources, there are problems concerning the interpretation of its meaning. For example, resource replacement cost can be viewed as merely a convenient measure for compensation without implying actual restoration of the natural resource to its previous state. Alternatively, it can be viewed as including the costs of actually restoring the natural resource habitat to its previous state and then replacing damaged organisms. Another disadvantage of the replacement cost method is that it is argued to be an arbitrary valuation of natural resources that may bear little relationship to true social value. The resource replacement cost method requires data on the costs to restore, rehabilitate, or replace injured or lost resources and resource services.

\section{Nonmarket Valuation: Indirect Techniques}

Using market-based techniques to measure the monetary value of natural resources is feasible provided there is sufficient market data. In many cases, however, market information relating to prices and quantities is not available to estimate the value of the resource or resource service. In these cases, researchers must employ what are referred to as nonmarket valuation methods. These methods include indirect techniques that rely on observable behavior in order to deduce how much something is worth to individuals. Value estimates obtained using indirect nonmarket valuation techniques are conceptually identical to the otherwise unobservable market value. The indirect nonmarket valuation techniques considered in this section include the travel cost method, the random utility method, the hedonic pricing method, and the factor income method. 


\section{Travel Cost Method}

The travel cost method is popular for describing the demand for the natural resource service(s) and environmental attributes of specific recreational sites. Designated wilderness areas, ecological parks, fishing and hunting sites, and scenic sites are examples. People visit such sites from diverse distances or points of origin. This observed "travel behavior" is then used to evaluate the willingness to pay to visit the site; essentially, the different travel costs from these diverse points of origin serve as proxies for willingness to pay to visit the site.

Intuitively, one would expect that the environmental attributes of sites influence the use of these sites. As such, changes in visitation rates may reflect changes in the quality of natural resources particular to the site, thereby providing an estimate of the value of changes in natural resource and environmental quality.

By gathering information on the number of visits to a particular site, the analyst can estimate a demand function for the site that relates the number of site visitations to the amount of travel costs incurred per visit, taking into consideration a set of independent household variables. If first-hand information on individual visitation rates is not available to the analyst, users of the site can often be grouped into travel zones around a site. Variations in visitation rates across zones can then be used to estimate the site demand function. In this way, travel cost models provide benefit measures for changes in environmental quality found at sites, based on the observed behavior of recreational site users. Among the key advantages of applying the method at DOE sites is its adaptability to many environmental quality issues where changes in quality affect the desirability of potential recreation sites.

In addition, the travel cost method can be easily implemented using phone, onsite or mail surveys, or site registration data. In some cases, survey data may be available from local, state, and federal resource management agencies to obtain travel cost estimates of site values. The technique is generally not perceived as being particularly controversial, 
partly because of its long history in forestry economics, but mostly because it mimics common empirical techniques used elsewhere in economics. Analysts have tended to look favorably on the travel cost approach to natural resource valuation because it is based on actual behavior rather than verbal responses to hypothetical scenarios. Individuals are actually observed spending money and time, and their economic values are deduced from their behavior. In appropriate circumstances, travel cost models can often be applied without enormous expense.

The greatest disadvantage of travel cost and other indirect techniques is that they cannot be used unless there is some easily observable behavior that can be used to reveal values. In addition, travel cost models can be technically and statistically complicated. Data must be employed to statistically estimate increasingly sophisticated econometric models that take into account sample selection problems and nonlinear consumer surplus estimates. In addition, the resulting estimates sometimes have been found to be rather sensitive to arbitrary choices of the functional form of the estimating equation, the treatment of the value of an individual's time, the existence of multiple stops during the travel period, and the recognition of substitute sites. Finally, the travel cost approach requires that the analyst be in a position to correlate environmental changes with the behavior of visitors. Example 4 provides an illustration of the method, taking these caveats into account.

\section{Random Utility Models}

Random utility models are conceptually linked with the travel cost models in that they seek the same sorts of values and use the same sort of logic. However, random utility models provide a different structure in which to model recreational demand, one which focuses attention on choices among substitute sites for any given recreational trip instead of the number of trips taken to a given site. These models are especially 


\section{Example 4: Travel Cost Model}

Scott et al. (1997) used the travel cost method to estimate willingness to pay for upland bird hunting in Benton-Franklin Counties in eastem Washington state.

Valuation data were obtained from the Washington State Department of Fish and Wildlife (Upland Game Division) and the "1991 Washington Survey of Fishing, Hunting, and Wildlife Associated Recreation." The authors apportioned travel by upland bird hunters to Benton-Franklin Counties into five zones based on state averages: those that travelled less than 25 miles to their hunting site, between 25 and 50 miles, between 50 and 100 miles, between 100 and 250 miles, and over 250 miles.

The authors estimated that the average cost per small game hunter in 1991 was $\$ 193$, and assumed that this cost varied in proportion to distance travelled to Benton-Franklin Counties. Given the latter assumption, they estimated an average cost per zone by multiplying the average cost of $\$ 193$ by the ratio of the median distance in each zone to the average distance travelled. Using this estimation of travel costs, willingness to pay for hunting shrub-steppe dependent game birds was estimated for the individual hunting zones and then aggregated across zones to obtain a willingness-to-pay estimate of $\$ 3.2$ million in annual recreational benefits.

Source: Scott, M. J., et al. 1997. "The Valuation of Ecological Resources and Functions." Environmental Management (forthcoming).

suitable when substitution among quality-differentiated sites is a predominant characteristic of the problem. That is, this type of model is particularly appropriate when there are many substitutes available to the individual and when the change being valued is a change in the quality characteristics of one or more site alternatives.

Random utility models originated in the transportation literature (McFadden 1981; Ben-Akiva and Lerman 1985) and only recently have been applied to recreation issues. Applications include studies of ski areas in Colorado and coastal fishing sites in Oregon (Morey 1981; Morey et al. 1991) and an extensive model of sport fishing in southcentral Alaska (Carson et al. 1987). The random utility model has been used chiefly to value changes in the specific characteristics of a site such as catch rates or water quality. These site characteristics, included in the estimation, are instrumental in explaining how individuals allocate their trips across sites. The random utility model can also be 
used to value the losses from eliminating a site as well as the value of introducing a new site, something beyond the scope of travel cost models.

\section{Example 5: Random Utility Modeling}

Morey et al. (1991) considered the demand for, and benefits from, marine recreational fishing along the Oregon coast. The study estimated consumer surplus of different individuals relative to changes in species availability (particularly salmon) due to changes in ecological conditions in the Columbia River. The data for this analysis were obtained from a 1981 National Marine Fisheries Service intercept survey along the Pacific coast. Anglers were interviewed at numerous fishing sites along the Oregon coast. Information was collected about their trip and their catch, but not their distribution of trips across sites. Other angler-specific information collected included county of residence, expense of the trip, and total number of trips during the last 12 months. The average per-trip costs (travel cost plus the value of time) in the sample of anglers varied from $\$ 4.83$ to $\$ 329.24$, depending on the county of origin and their final destination. The authors reported considerable variation in catch rates across sites, modes of fishing, and fish species. Many of the catch rates were assumed to equal zero because not all species are available at the various fishing sites. The largest catch rate was reported to be 6.85 for rockfish from charter boats in Coos Bay.

Morey et al. used a discrete-choice random utility model to estimate the number of times an individual will participate in a given type of site-specific activity and which site will be selected on each trip, given different supply conditions for the natural resource. The individual consumer's surplus was measured by the "ex-ante seasonal compensating variation," which reflected changes in such characteristics as personal household income. For example, the consumer's surplus from visits to Clatsop County was associated with the elimination of either on-shore, offshore, or all fishing opportunities in the county. Each individual's measure of consumer's surplus for the fishing season was then obtained by multiplying their seasonal consumer's surplus by the estimated number of seasons.

The study found that an angler from Clatsop County will pay $\$ 111.62$ before the season starts to be able to fish from an on-shore mode in Clatsop throughout the season. An angler from Tillamook will pay $\$ 67.52$ for the same option, but an angler from Curry County will pay only $\$ 5.88$. These differences in value illustrate that an angler will pay for the opportunity of fishing at a site/mode that he/she might actually never visit, but the amount is small unless there is a significant probability that the angler will visit that site/mode. Multiplying each individual compensating variation by the number of anglers in a county and summing across counties gives an estimated aggregate yearly compensating variation of $\$ 4.2$ million for the elimination of all the modes in Clatsop County. This is an estimate of how much all of the anglers in Oregon would have paid for the option of going fishing in Clatsop County in 1981.

Source: Morey, E. R., et al. 1991. "A Discrete Choice Model of Recreational Participation, Site Choice, and Activity Valuation When Complete Trip Data Is Not Available." Journal of Environmental Economics and Management 20:181-201. 
Unlike travel cost models, however, random utility models cannot explain the total number of trips an individual takes to a given site in a season. Nonetheless, random utility models would seem to provide a useful technique for comparing benefits of site restoration or decontamination activities across waste sites at federal facilities. To the best of our knowledge, no such applications have been undertaken.

\section{Hedonic Price Method - Amenity Value}

Hedonic pricing is a useful tool in the assessment of amenity value. Early analysis related residential property values to neighborhood amenities. These models provided an inferential measure of people's willingness to pay for the amenity under study. The method is used mostly to estimate the willingness to pay for variations in property values due to the presence or absence of specific environmental attributes, such as air quality, noise, and panoramic vistas. By comparing the market value of two properties having different degrees of a specific attribute, analysts extract the implicit value of the attribute to property buyers and sellers. A variation on the approach is to compare the price of a single piece of property over successive sales. By correcting for other factors that might have influenced the value of the property, the analyst can isolate the implicit price of an amenity or bundle of amenities that have changed over time.

Consider the impacts of the completion of a DOE environmental restoration activity on the price of neighboring land. At one time, the proximity of the parcel of private property to an abandoned DOE waste site may have reflected the disamenities of living in a hazardous environment. Years later, upon restoration of the site, the hedonic model would suggest an implicit value for DOE investments in environmental improvements. Similar analogies can be drawn in relation to the estimation of monetary damages to natural resources from environmental 
disamenities, or the monetary benefits of investing in their improvement. Accordingly, hedonic pricing methods appear to be well suited to DOE planning work involving Environmental Impact Statements (EISs) and Natural Resource Damage Assessments.

However, the reader should be made aware of caveats pertaining to the values obtained from hedonic price functions. In particular, the resource values that are obtained directly from the estimated hedonic price function are subject to fairly restrictive assumptions. It may be necessary to employ additional information from multiple commodity markets relating to the resource under consideration. Overall, the resulting hedonic price will depend on the availability of market information pertaining to the resource, and the revelation of buyer and seller preferences through market behavior. Market data on property sales and characteristics are available through real estate services and municipal sources and can be readily linked with other secondary data sources. Despite these positives, a guarded interpretation of the estimated welfare changes is recommended. Estimation and interpretation of these measures can be complex and the data requirements demanding, and there is a need to control for many important socio-demographic characteristics.

\section{Hedonic Price Method - Value of Life}

Hedonic pricing methods have also been applied in the estimation of economic damages associated with occupational health and safety risks and are becoming more widely accepted in the determination of personal injury awards in liability cases. Application in this branch of the hedonic valuation literature often refers to the "value of life". or the "hedonic value of life." Clearly, there is no such thing as a unique value of life. Consequently, meaningful estimates of the hedonic value of life vary according to the specific context under consideration. For one, it must be made clear whose value is under consideration: Is it a worker who understands and accepts a health/safety risk, or is it a 


\section{Example 6: Hedonic Price Method - Amenity Value}

The hedonic method was used in the Eagle Mine case (Kopp and Smith 1992). The plaintiff/rustee, the state of Colorado, contended that operation of the Eagle Mine facility near Gilman, Colorado, resulted in release of a variety of hazardous substances into the groundwater and the Eagle River and may have affected some portions of public land adjoining the river. These effects arose primarily from the disposal of mine tailings. As a direct result of the release, the trustee contended, several services provided by the Eagle River diminished both in quality and quantity. These services included recreational activities on the river, such as fishing and boating, and recreational activities near the river, such as hiking and camping. Moreover, because of these releases in the river, the plaintiff argued, its aesthetic quality had been impaired, leading to a decline in the value of adjacent properties. Finally, some private wells used for drinking water were thought to have been contaminated.

To evaluate the natural resource damages associated with these effects, the trustee used methods based on U.S. Forest Service estimates of the values per day of alternative recreational experiences $(\$ 14$ per day for water-based recreation and $\$ 9$ per day for nonwater-based recreation), two contingent valuation surveys, and a hedonic property value model. The hedonic price model was based on responses to the sunvey of Eagle County residents who answered a question about the purchase price for their homes, which were situated within 25 miles of the Eagle Mine. A variable indicating whether the home was within six miles of the mine was used to represent the effects of the mine. The objective of this model was to obtain estimates of damage due to possible contamination of local drinking water supplies and to blowing dust from the Eagle Mine tailing piles.

Unfortunately, the hedonic technique fails to capture all aspects of this proximity to the Eagle Mine. Moreover, because the differences in property values due to proximity to the Eagle Mine represent capitalized differences in the flow of services from the injured natural resources, the results of the hedonic model represent the present value of all perceived future damages. Nonetheless, the results of the study suggest a property devaluation amounting to $\$ 24,400$ for property located within six miles of the Eagle Mine. Because 500 residences were located within the six miles, the plaintiff claimed an aggregate damage estimate of $\$ 12.2$ million.

Source: Kopp, R. J., and V. K. Smith. 1992. "Eagle Mine and Idarado." In Natural Resource Damage: Law and Economics, K. M. Ward and J. W. Duffield (ed.), John Wiley and Sons, Inc., New York, pp. 365-388.

passer-by who is unaware of the risk but nevertheless is predisposed to some adverse health impacts? Moreover, does the hedonic value under consideration concern the prevention of adverse health consequences from a potential accident, or does it concern an after-the-fact compensation to be given to survivors of an accident? To better understand the 
significance of these questions, it is instructive to clarify the concepts that are involved by distinguishing between two basic hedonic damage values: the insurance value and the deterrence value.

Insurance value is the amount that an individual is willing to pay to ensure a preferred level of welfare, assuming a) that they fully understand the risk to which they are predisposed and b) that the costs of buying insurance are in perfect correspondence to the specific risk under consideration. Meanwhile, deterrence values are used by leading practitioners as the appropriate measure of compensation value that should be charged from the standpoint of the accident victim. The amounts generally exceed the insurance value, as these tend to reflect individual attitudes towards all consequences of the risk. This would include the value that the individual has attached to the risk of experiencing the injury, losing income as a result of the injury, and losing the ability to enjoy life.

Conceptually, these two hedonic value-of-life measures can be used to determine the amount of compensation required to make the accident victim(s) whole by either restoring or maintaining a benchmark preaccident level of welfare. One of the most important results identified in the literature is that workers who are predisposed to a typical occupational injury would select an amount of insurance compensation below that which would be required to completely restore their pre-accident level of welfare.

To illustrate the potential applicability of hedonic value methods, consider the accompanying example, which involves estimating the monetary benefits of meeting regulatory safety or compliance standards, such as the attainment of ALARA dose limits. In considering this example, the reader should keep in mind that there are added ambiguities in determining hedonic value-of-life estimates in the context of human health risks accompanying environmental restoration and waste management activities. More specifically, there is apt to be a varying 
degree of onsite and offsite uncertainty associated with waste stream characteristics, the extent of toxic discharges, or transport pathways to human receptors.

\section{Example 7: Hedonic Price Methods - Value of Life}

Consider a situation in which an ER worker faces a relatively small risk of losing his life, one that is equal to the average hazard posed by a typical job - an annual risk of death of 1 in 10,000 accidents. Assume that a hedonic wage study of risk preferences across ER workers is undertaken thereby revealing that such workers are willing to accept an annual wage premium (or income compensation) of $\$ 500$ in order to face this risk of death. Together, the presence of the health risk and the hedonic value estimate of the required wage offset establish the "risk-dollar tradeoff" for the typical worker. In other words, they establish a price for bearing human health risk. In this example, $\$ 500$ compensation for each risk of $1 / 10,000$ of death implies a total compensation level per statistical death of $\$ 5$ million.

Assume next that risk mitigation measures are taken that effectively reduce the chances of an accident by one-half, consistent with an ALARA-calibrated risk involving the potential death of 1 in 20,000 accidents (or what is equivalent to 0.5 in 10,000). Assuming that workers risk preferences remain unchanged as reflected by the $\$ 500$ wage offset, the compensation level per statistical death would also be reduced by one-half: from $\$ 5$ million to $\$ 2.5$ million. In this example, the savings of $\$ 2.5$ million would reflect the benefits of the ALARAcalibrated risk. As a measure of deterrence value, this $\$ 2.5$ million reflects the workers' valuation of risk-mitigating measures. In this way, hedonic value estimates concerning human health and safety would appear to have particular relevance in measuring the benefits of achieving ALARA-type standards.

Source: Adapted from W. Kip Viscusi. 1990. "The Value of Life: Has Voodoo Economics Come to the Courts?" Joumal of Forensic Economics 3(3): 1-15.

\section{Factor Income Method}

The factor income method is used as a means of valuation in applications where natural resources are used as inputs in the production of other goods and services. Accordingly, the resulting economic costs of production are an important source of information in applying the factor 
income approach. While the method of factor income is not as welldefined or widely referenced as the hedonic price or travel cost methodologies, it is recognized by the U.S. Department of Interior's natural resource damage assessment regulations.

There are several types of resources for which the factor income approach is potentially well-suited, including surface water and groundwater resources, forests, and commercial fisheries. Surface and groundwater resources may be inputs to irrigated agriculture, to manufacturing, or to privately owned municipal water systems. The products in these cases (agricultural crops, sawlogs, manufactured goods, and municipal water) may all have market prices. Similarly, commercial fishery resources (fish populations or stocks) are inputs to the production of a catch of saleable fish. A variation on this theme may be useful for valuing damages to water resources.

In cases involving damages to water resources that are used in production processes, for example, one might identify the incremental cost of treating water sufficiently to return it to the pre-release water quality level. For example, a manufacturer who already engages in some form of water treatment as part of its production process might experience increased treatment costs because of hazardous substance releases upstream. If all other things are unchanged (product price, the mix of inputs in the production process, output levels), then the increased cost per unit of "clean water" provides a measure of lost factor income.

This approach is convenient in that the costs of treating water are separated from other production costs incurred in the manufacturing process. Similarly, the example suggests that treatment costs might be applicable to a wide variety of situations of interest to DOE field operations.

There are, however, potential problems in applying the factor income approach. First, a particular treatment option might not be the least-cost or optimal response on the part of the water-using entity. For example, it might be cheaper to change the production process, buy municipal 
water or otherwise obtain a different source of water, or make other changes to the equipment or materials used. In this case, changes in water treatment costs may overstate damages. Second, it is possible that other things may change, particularly price and output levels. These potential problems can complicate the analysis and require the researcher to obtain additional technical information concerning the supply and demand of the underlying resource or resource service.

\section{Nonmarket Valuation: Contingent Valuation}

Given the potential shortcomings in applying indirect nonmarket valuation techniques, researchers have advanced the use of a more direct approach, namely contingent market valuation. Contingent market analysis has estimated a wide variety of use and nonuse values.

The most obvious way to measure nonmarket values is to ask people how much they would be willing to pay for the resource or avoid any damages that might be sustained by the resource. Alternatively, one could ask how much people would be willing to accept as compensation for damages to the resource. Measures obtained using this technique rely on people's hypothetical willingness to pay rather than actual market-information on their behavior: hence, the term contingent valuation (CV). The contingent valuation method is a survey-based approach to the valuation of nonmarket goods and services. It uses questionnaires to elicit information about the preference-related value of the natural resource in question. The value is said to be contingent upon the existence of a hypothetical market as described in the survey put to respondents. In principle, contingent valuation could be used to estimate the economic value of almost anything. By default, it is the only method that holds the promise of measuring nonuse values since all other methods depend on observing actual behavior associated with the natural resource. 
Contingent valuation surveys may be conducted as face-to-face interviews, telephone interviews, or mail surveys based on a randomly selected sample or stratified sample of individuals. Face-to-face interviews are the most expensive survey administration format, but they are generally considered the best, especially if visual material needs to be presented. The central goal of the survey is to generate data on respondents' willingness to pay for (or willingness to accept) some program or plan that will impact their well-being.

Each respondent is given information about a particular problem. Each is then presented with a hypothetical occurrence (e.g., specie endangerment) or a policy action that ensures against the disaster (e.g., specie protection). Each respondent is asked how much he/she would be willing to pay either to avoid the negative occurrence or bring about the positive occurrence. The means of payment (i.e., the payment vehicle) can take on any number of different forms, including a direct tax, an income tax, or an access fee. The actual format may take the form of a direct question ("how much?"), a bidding procedure (a ranking of alternatives), or referenda votes. Using a referendum to elicit values is preferred because it is the one that people are most familiar with. Resulting data are then analyzed statistically and extrapolated to the population that the sample represents. These responses are gathered along with socio-demographic information and test statistics required to determine the consistency of responses and the sensitivity to scope.

When conducted according to the exacting standards of the profession, these studies can be very expensive because of the extensive pre-testing and survey work. In addition, while this technique appears easy, its application involves numerous technical challenges. For example, applications of the method are prone to strategic biases on the part of respondents or to structural problems in the design of the questionnaire (Mitchell and Carson 1989). Question framing, mode of administration, payment formats, and interviewer interactions can all affect the results of contingent market valuation (Cummings et al. 1986). 


\section{Example 8: Contingent Valuation Method}

The Eagle Mine case study (Kopp and Smith 1992) exemplifies how contingent valuation methods can be applied in resource damage assessments. Contingent valuation questions were presented in both an Eagle County and a statewide survey, to elicit respondents' willingness to pay for the Eagle River cleanup. The Eagle County survey asked respondents about their willingness to make annual payments over 10 years to clean up 200 waste sites involving current legal action. Respondents were given brief descriptions of each site. The survey requested each respondent to perform two allocations: 1) specify from a schedule of percentages the percent of their total bid for all sites that they would like to assign to the seven sites, and 2) identify a most important site among these seven and the percentage of their bid they would like to have allocated to this one particular site. In addition, respondents were asked to allocate the percentages of their total bid (for cleanup of all 200 sites) that they associated with use and nonuse values. The table below details the results of the analysis. In the Eagle County survey, questions were designed so that the willingness to pay estimates included both use and nonuse values, but allowed for the disaggregation of water and nonwater-based values. In the survey of Colorado residents, no differentiation between waterbased and nonwater-based values was possible, but an allocation between use and nonuse values was made. The table displays the mean estimates of annual willingness to pay derived from each survey. In the case of Eagle County residents, the analysts multiplied the annual mean willingness-to-pay estimates by growth of 6063 households, carried forward for 10 years, assuming a population growth of 2 percent, and then discounted back to 1985 at 10 percent. The analysts employed a similar aggregation procedure for the statewide estimates.

\section{Eagle Mine Case Contingent Valuation Estimates}

\begin{tabular}{|c|c|c|}
\hline Contingent Valuation & $\begin{array}{l}\text { Unit Darnage Estimate } \\
(\$ 1983)\end{array}$ & $\begin{array}{c}\text { Discounted Present Value } \\
\text { of Future Damage } \\
\text { (Aggregate Estimate) }\end{array}$ \\
\hline $\begin{array}{l}\text { Eagle County willingness-to- } \\
\text { pay survey: } \\
\text { - Use and nonuse values } \\
\text { (water-based) } \\
\text { - Use and nonuse values } \\
\text { (nonwater-based) }\end{array}$ & $\begin{array}{l}\text { \$73 per year/household } \\
\text { \$30-51 per year/household }\end{array}$ & $\begin{array}{l}\text { County residents } \\
\$ 3.4 \text { million } \\
\text { County residents } \\
\$ 1.5 \text { million }\end{array}$ \\
\hline $\begin{array}{l}\text { State of Colorado willingness- } \\
\text { to-pay survey: } \\
\text { - Use values } \\
6,063 \text { households in } \\
\text { Eagle County } \\
\text { - Nonuse values } \\
1.2 \text { million households } \\
\text { in Colorado }\end{array}$ & $\begin{array}{l}\$ 1.80 \text { per household } \\
\$ 3.80 \text { per household }\end{array}$ & $\begin{array}{l}\$ 15 \text { million State residents } \\
\$ 30 \text { million State residents }\end{array}$ \\
\hline
\end{tabular}

Source: Kopp, R. J., and V. K. Smith. 1992. "Eagle Mine and ldarado." In Natural Resource Damage: Law and Economics, K. M. Ward and J. W. Duffield (ed.), John Wiley and Sons, Inc. New York, pp. 365-388. 
The quality of a contingent valuation survey questionnaire is sensitive to the amount of information that is known beforehand about the way people think about the underlying natural resource. Certainly, prior information on the ecological attributes or environmental qualities of a particular resource are critical factors in conducting a successful contingent valuation survey. The key point is that, while all the information necessary for assessing an individual's value of the resource is collected in the survey, the analyst must also be able to identify a truly representative sample of well-informed respondents in order to allow extrapolation to the general subject population. Thus, information on who uses the resource and who knows about it is critical.

\section{Cross-Cutting Methods}

At the present time, there is considerable professional interest in natural resource valuations that are based on cross-cutting methods. These valuation techniques combine elements from market-based methods with pre-existing estimates of natural resource values based on either direct or indirect nonmarket valuation techniques. The interest in applying cross-cutting techniques is motivated by the relative simplicity of using a pre-existing study based on an accepted method, as well as the cost considerations in undertaking a fresh natural resource valuation study. Two cross-cutting resource valuation techniques that have gained increased professional attention due to their simplicity and economy of application are discussed here: benefit transfer and unit day value.

\section{Benefit Transfer}

Benefit transfer is the use of the estimated values or demand relationship in existing studies to evaluate a site or event for which no sitespecific study is available. Given the expense and time associated with the estimation of values of nonmarket natural resources and services, 


\section{Example 9: Benefit Transfer Method}

Ulibarri and Ghosh (1995) provide a willingness-to-pay estimate to reduce high particulate matter $\left(\mathrm{PM}_{10}\right)$ levels using the benefit-transfer method. Their application focuses on willingness-to-pay estimates for improved visibility in Benton-Franklin Counties in eastern Washington state. The authors' estimates are based on key parameter values derived by Rowe et al. (1980) using a CV survey instrument. In using the Rowe et al. parameter estimates, the authors note that their commodity specification (quality of visibility) is similar to the one evaluated by Rowe et al. However, to capture the aesthetic realities of the study site, the authors obtained daily observations of $\mathrm{PM}_{10}$ levels over the period 1990 1994 from the Benton-Franklin County Clean Air Authority. In addition, the authors adjusted the various independent variables identified in Rowe et al. using countylevel census data on the urban/rural population, age distribution, ethnicity and gender, and the levels of household income. Upon making these adjustments, the authors found a measure of the collective willingness to pay across 54,000 household in the Benton-Franklin area of approximately $\$ 364,395$ per exceedance day, i.e., a day on which $\mathrm{PM}_{10}$ levels equal or exceed 150 micrograms per meter, the safe minimum standards under the Environmental Protection Agency's National Ambient Air Quality Standards.

Source: Ulibarri, C. A. and S. Ghosh. 1995. "Benefit-Transfer Valuation of Ecological Resources." Pacific Northwest National Laboratory, Richland, Washington; and Rowe et al. 1980. "An Experiment on the Economic Value of Visibility." Joumal of Environmental Economics and Management, 1-19.

benefit transfer may be a reasonable method by which to determine such values under well-defined conditions. The analyst should consider all available estimates at the onset of the study. Each estimate should be evaluated by comparing the methodology and results of the original studies that may have been undertaken in selecting one that best matches the policy study under consideration. The following criteria have proved to be potentially useful in making this determination:

- purpose of original value estimates

- user group(s) considered

- nature of substitutes in the initial study area

- geographic area 
- demographic and socio-economic characteristics

- baseline conditions

- $\quad$ specific or unique problem that may be influenced by the magnitude of the estimates

- general attitudes, perceptions, or levels of knowledge

- omitted variables described above.

Once a final set of values has been chosen, consideration should be given to the general magnitudes of the values. If the existing value estimates differ significantly, or if values generated using alternative models differ significantly from one another, consideration should be given to whether they differ in a predictable and consistent manner. In many cases, the defensibility of the transferred economic benefit estimate will depend on the quality of the underlying research. There are no globally accepted, standard criteria by which the quality of existing studies can be judged. Decision-makers should, therefore, seek the guidance of the professional and academic economics community concerning the current minimum conditions for accurate use of the benefit transfer method.

\section{Unit Day Value Method}

The unit day value method is similar to the benefit transfer method, except that an average value is derived based on multiple value estimates from existing studies. Consequently, the unit day value of the underlying resource reflects a resource having average preferencerelated attributes, amenities, or qualities. Any of the valuation approaches described above can potentially serve as underlying studies from which unit day values are drawn. The application of the unit day 


\section{Example 10: Unit Day Value Method}

As in many small natural resource damage cases, Loomis and Anderson (1992) relied on existing data and previously estimated equations and values to determine the value of recreational fishing lost as a result of the 1987 spill of Vitavax 200 (a fungicide) in Idaho's Little Salmon River. in attempting to assess damages, Loomis and Anderson found there were no economic valuation studies directly related to the Little Salmon River. To keep assessment costs low, the decision was made not to perform a new study specific to the Little Salmon River but rather to rely on the existing economic survey dala. They used a travel-cost demand analysis for several segments of the main Salmon River above and below its confluence with the Little Salmon River, previously undertaken by Donnelly et al. (1985). These data had been collected and analyzed as part of an interagency state-federal research effort spanning 1982 to 1985 . The survey design and travel cost methodology used in the study followed the spirit of the U.S. Water Resources Council Principles and Standards.

The sample was drawn from a list of individuals who had purchased an Idaho steelhead tag for the 1982 season. The combined mail and telephone survey of 427 anglers had a response rate of 100 percent. The travel-cost equation and associated values per trip had been peer-reviewed prior to publication as a U.S. Forest Service Experiment Station Bulletin. The available data had been used to estimate a simple quality-augmented zonal travel-cost demand curve. Specifically, one multi-site pooled regional travel-cost demand was estimated for the 11 sections of the Saimon,

Clearwater, and Snake Rivers where steelhead fishing was allowed in 1982 . Using this demand curve, a value of $\$ 25.94$ per trip had been calculated for the segment of the Salmon River just downstream from the Little Salmon River. The authors recalculated the per-trip value of $\$ 25.94$ to a value per steelhead, using information that it took 1.36 trips per steelhead caught. This resulted in a value per steelhead of $\$ 35.28$. Updating this value from 1982 dollars to 1987 dollars yields $\$ 41.52$ per fish. With average catch rates, half of the 1688 returning adult steelhead would be recreationally caught. Therefore, the value of the 844 steelhead that were lost due to the spill that would have otherwise been caught was $\$ 35,045$.

Sources: Loomis, J., and Anderson, P. 1992. "Idaho v. Southern Refrigerator." In Natural Resource Damages: Law and Economics, Ward, K. M. and Duffield, W. J. (ed.) Wiley Law Publications, New York, pp. 389-414; and Donnelly, D. M., J. B. Loomis, C. F. Sorg, and L. J. Nelson. 1985, Net Economic Value of Recreational Steelhead Fishing in Idaho. U.S. Forest Service Bulletin RM-9, Rocky Mountain Forest and Range Experiment Station, Fort Collins, Colorado. 
value method may also involve groups of experts attempting to interpret from the existing set of estimates (regardless of method used in the original study) a best estimate for each of a set of generic types of environmental resources or activities. The unit day value approach then combines and converts these estimates into a standardized unit of measure that reflects the average value of one unit of the resource on a perday basis.

In some cases, unit day values head part-way toward a reasonable benefit transfer approach by developing general categories across activity types or geographical locations. However, unlike benefit transfer, there is no attempt to identify previous studies for comparable sites. For example, the U.S. Water Resources Council guidelines provide unit values across fairly broad activity types and settings. Similarly, the U.S. Forest Service has developed unit values that are specific for activity types and Forest Service regions. However, the analyst must exercise caution when applying such unit day values, insofar as they may reflect a biased selection of studies that reflect poorly on the existing economic value of the natural resource.

\section{Ecological Valuation}

The conventional natural resource valuation techniques described above have made little progress in providing a framework to assess the monetary value derived from ecological functions. One reason is that ecological functions are often overlooked in terms of providing preferencerelated value to humans. Thus, the state of the art in natural resource valuation is in search of a framework for addressing natural resource values derived from ecological functions. This section first briefly discusses the emerging field of ecological economics. It then considers gross primary energy valuation and non-glamorous resource valuation, which are two approaches to measure ecological values in the emerging field of ecological economics. 


\section{Ecological Economics}

Although controversial, some resource valuation professionals believe that changes in the service flows from ecological systems to human society can be valued in monetary terms, given existing knowledge, scientific data, and estimation techniques. They believe that this would bring such services into management discussions in terms symmetric with marketed goods and services. As a general matter, this could improve the efficiency with which society uses resources. One reason for this view is the belief that such pricing would encourage preservation by making explicit the opportunity cost of development and other economic activities. These people support the continued refinement and extensions of economic valuation techniques based on people's preferences over ecological resources.

Other experts express serious reservations about the prospects of deriving willingness-to-pay estimates for ecological resources. Their distrust arises in part because of the potential lack of knowledge associated with people's understanding of ecological functions and how ecological systems are damaged through human activities. Without a firm understanding of the ecological impacts of human intervention, there is no reliable way to estimate meaningful ecological damage. Accordingly, there is skepticism as to whether monetary values can be assigned to damages that might arise within the intricate web of ecological interdependencies in both small- and large-scale ecosystems. Nevertheless, monetary values are beginning to surface in the ecological economics literature. One approach is based on the energy valuation of gross primary production, which incorporates both economic and ecological values in one index. 


\section{Gross Primary Energy Valuation}

This procedure has been applied to the valuation of different wetland types (Constanza et al. 1989). It is argued that estimates of gross primary production have merit since the entire food chain depends upon this primary production. The methodology is not without its problems, however. For instance, it is not well understood whether those species supported by a particular food chain have equal social values. In general, the embodied energy approach measures only ecologically based values. Unlike an economic valuation approach, values for such functions and services as storm protection, aesthetics, and water treatment are completely ignored.

Recently, an alternative cross-cutting approach to environmental issues has come under the rubric of ecological-economic valuation. A team of ecologists and economists sponsored by the U.S. Environmental Protection Agency (EPA) has undertaken the development of a crosscutting model of an ecological-economic system (i.e., the Maryland Patuxent Watershed), with emphasis on wetlands. Preliminary work is based on a coastal ecological landscape spatial simulation model developed by Robert Costanza and colleagues from the University of Maryland. Ultimately, the cross-cutting model may incorporate economic behavior, thereby capturing interrelationships between human activities, the ecosystem, and ecological valuation. A related attempt at employing cross-cutting techniques in determining ecological values is based on the recognition that humans may have preferences relating to the functions and services performed by ecological resources, referred to as ecological resource valuation.

\section{Ecological Resource Valuation}

The need for a framework addressing the value of ecological functions is particularly acute in assessing policy choices that affect the integrity of ecological systems. Using the example of wind-blown dust, Ulibarri 
and Ghosh (1995) suggest that these policy decisions require a weighting of ecological values based on two related subsets of information: what is valued by humans as an eco-good (i.e., cleaner air) and what has intrinsic value to the natural eco-system (i.e., vegetative cover). Using the term ecological resources, the authors focused attention on resource services that are functionally important to ecosystems but frequently overlooked in terms of providing value to humans. Such resources have received very little attention relative to their more glamorous cousins, such as endangered salmon runs or old-growth timber stands.

The authors note that the key objectives of ecological resource valuation are a) to provide a framework that aggregates the values of goods and services rendered by selected ecological functions and $b$ ) to determine defensible upper and lower limits on these values. The possibility of interpolating between these limits would enable a more robust estimation of the value of eco-goods and services, allowing policy makers to form a more complete understanding of the benefits and costs of ecological preservation.

The preliminary work undertaken by Scott et al. (1997) considered social values associated with undeveloped shrub-steppe sites; these are arid environs which are traditionally overlooked in land-use decisions. Relative to the perceived values, the authors attempted applications of the benefit transfer method, the travel cost method, and the method of hedonic damage-pricing. In order to estimate the intrinsic values of natural ecosystems, they applied a replacement cost methodology based on the idea of replacing the functions performed by the natural ecosystem through a human engineered analog. Using these cross-cutting resource valuation techniques, the authors maintained that the economic value of shrub-steppe sites reflects both their ecological services and recreational uses. Given the uncertainty that exists as to the social benefits from preserving undeveloped shrub-steppe, they suggest the need for further analysis in order to establish credibility in ecological site valuations. 


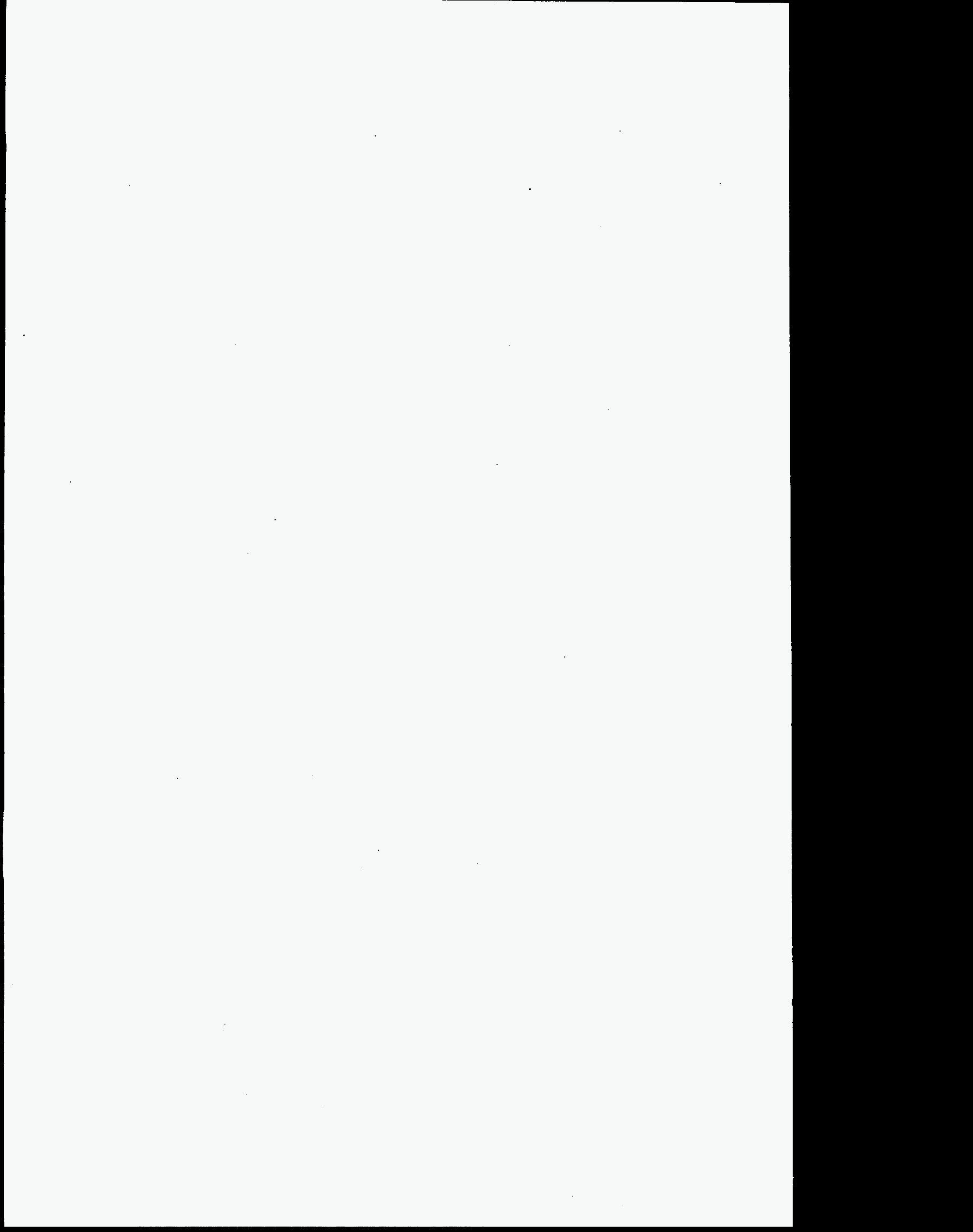




\section{Unresolved Issues}

The following discussion focuses on a series of distinct and challenging issues in the valuation of natural resources and the environment: a) the choice of a discount rate in assessing the present and future values of benefits and costs; $b$ ) the individual's time-preference in deriving benefits over the near term as opposed to later on; c) the role of equity and fairness in resource valuations involving present and future generations; d) the conceptual understanding of risk and uncertainty in the valuation of natural resources and the environment; and e) qualification of the measurement errors in the application of the natural resource valuation techniques discussed in this handbook. Without identifying the potential importance of these factors in the valuation process, the analysis of natural resource values will remain incomplete and contentious if used by DOE field operations as a basis for decision-making.

\section{Discounting and Time Preference}

Discount rates enable one to determine the present value of the benefits and costs associated with the future use and enjoyment of natural resources. If the analyst of future benefits and costs sets a high discount rate, say 10 percent, the present value of benefits in the distant future becomes insignificant when compared with the present value of benefits in the near-term future. For example, using continuous discounting at the rate of 10 percent, the present value of $\$ 1000$ of benefits obtained 2 years in the future is $\$ 818.73$, and in 10 years becomes $\$ 367.88$, less than half as much. By choosing a lower discount rate, say 2 percent, the analyst reduces this temporal bias: $\$ 1000$ of benefits 10 years hence becomes $\$ 818.73$. Given the implications of this basic 
arithmetic on natural resource valuations, it is no wonder there is so much controversy among economists, scientists, and policy makers over the applications of appropriate discount rates.

Despite the controversies that exist, discounting is part of applied benefit-cost analyses. Its main role is helping to evaluate a series of costs or benefits that are strung out over the future. Discounting is a way of adding up a series of future net benefits into an estimate of present value. However, as we have already seen, the outcome of this exercise depends on which particular discount rate we use. Under rates of 2 percent, we are essentially treating a dollar of benefits from a natural resource in one year as very similar in value to a dollar of benefits in any other year. Using very high rates, say above 7 percent, we are saying that a dollar of natural resource benefits in the near-term is much more valuable to us than it would be later on. Thus, the higher the discount rate used in the calculation of present values, the more we are favoring the near term use and/or enjoyment of natural resources relative to more distant future uses. To the contrary, the lower the discount rate used in present value calculations, the more equally we are weighing the benefits over time.

It follows that the choice of a discount rate is inextricably tied to the present generation's concern for resource values that will accrue to present and future generations. Consequently, resource stewardship requires consideration of subjective views on decisions which generate environmental benefits for present and future generations. This understanding can be captured analytically by the rate of social time preference: the rate at which society is willing to exchange consumption and enjoyment opportunities in the present for similar opportunities in the future.

The rate of time preference is frequently cited as a kind of subjective rate of interest. To an individual, time preference depends largely on tastes and preferences, income levels, age, and even socio-cultural norms. For example, consider an individual who is willing to forego 
limited access to an open-space site over a one-year period (say, while an ecological restoration is undertaken), with the understanding that he/she will be compensated by gaining additional access to the site upon completion of the restoration in the coming year. We mean by the word "compensation" that the individual is left feeling just as well off as if he/she had not given up access to the site - no more and no less. The degree of time preference is defined by the benefits he/she requires in the coming year in exchange for the benefits he/she will lose in the present year.

Beyond the level of the individual, however, the concept of time preference becomes all the more controversial by requiring us to make some very strong assumptions about the collective preferences of individuals over present and future consumption/use of natural and environmental resources. This difficulty has led economists to seek more practicable measures by relying on the following proposition: An individual will postpone further material consumption in order to lend on the capital market, provided the rate of interest exceeds his/her rate of time preference. Under the ideal circumstances of equilibrium in capital markets, it has been shown that the rate of time preference will equal the rate of interest. However, the analysts must proceed with caution in using interest rates observed in capital markets in the calculation of present values of natural and environmental resources. After all, there are likely to be some highly significant differences of opinion when it comes to the valuation of these resources as opposed to, say, a AAA-rated municipal bond.

The analyst must be aware that there are dozens of different interest rates in use at any one time - rates on normal savings accounts, certificates of deposit, bank loans, government bonds, etc. Which rate should we use? There are essentially two schools of thought on this question. The first is that the discount rate should reflect the way people themselves think about time. Any person normally will prefer a dollar today to a dollar in 10 years. In the language of economics, they have a positive rate of time preference. We see people making savings decisions 
by putting money in bank accounts that pay certain rates of interest. These savings account rates show what interest the banks have to offer in order to get people to forego current consumption. We might, therefore, take the average bank savings account rate as reflecting the average person's rate of time preference.

The second approach to determining the "correct" rate of discount is based on the notion of investment productivity. When investments are made in productive enterprises, people anticipate that the value of future returns will offset today's investment costs. Otherwise, these investments would not be economically efficient. The thinking here is that when resources are used in the public sector for natural resource and environmental programs, they ought to yield, on average, rates of return to society equivalent to what they could have earned in the private sector. Private-sector productivity is reflected in the rates of interest banks charge their business borrowers. Thus, by this reasoning, we should use, as our discount rate, a rate reflecting the interest rates that private firms pay when they borrow money for investment purposes. These are typically higher than savings account interest rates.

Real rates of between zero and 8 percent appear regularly in the economics literature. Some have even argued for negative discount rates to reflect the implicit interest of future generations in resource management decisions. The policy of the Office of Management and Budget (OMB), which provides guidance to most federal agencies on a discount rate for public investment and regulatory impact analyses, is based on the private opportunity-cost principle. This rate was recently changed from 10 percent to 7 percent. Some U.S. federal agencies responsible for managing natural resources employ significantly lower discount rates. For example, the Bureau of Reclamation reportedly uses an 8.875 percent nominal rate, which translates to a real rate of between 3 percent and 5 percent, depending on the assumptions made about the effective rate of inflation. The U.S. Forest Service and Bureau of Land Management employ a 4 percent real rate of discount in natural 
resource assessments. The National Oceanic and Atmospheric Administration has recently adopted a 3 percent to 4 percent discount rate (based on the Treasury rate) for natural resource damage assessments.

\section{Equity and Fairness}

The valuation of natural and environmental resources under ethical criteria diverges sharply from that of the conventional utilitarian approach. Land or water values provide some perspective on this. Assume, for example, that a tract of land is privately owned. Its market price reflects the private benefits that it can provide. If we assume there exists a well-specified system of property rights over the parcel of land, individual self-interest would lead to a negotiated settlement over the rights to buy or lease the land according to the marginal values of the land in its various alternative uses. It would be in the owner's selfinterest to ensure that the land would be allocated to those uses which command highest value before considering other uses which have lower marginal values. This typifies economically efficient resource allocations, whereby relatively lower-valued uses are effectively excluded from consideration. It makes no difference if the land were under public stewardship, because a similar means of allocation could be achieved by administering an auction for land-use rights, thereby ensuring that the land was used where it commanded highest value.

In contrast, applying the criteria of equity and fairness gives equal weighting to the various land uses. These criteria affect the application of existing property rights and give rise to shadow prices which reflect the administrative goals of providing equal use to all concerned parties. The political distribution of natural resources to achieve equity and fairness displaces the utilitarian value of land. Accordingly, the application of equity and faimess in the distribution of resources is complicated and controversial. Ultimately, distribution is a matter of who gets the benefits and who pays the costs. In public-sector 
programs, distributional matters must be considered along with efficiency issues, which implies that benefit-cost analyses must incorporate information on how net benefits are distributed among different groups in society. The distribution of benefits and costs is primarily a matter of equity or fairness. There are two main types of equity: horizontal and vertical. Horizontal equity is a case of treating similarly situated people the same way. Vertical equity refers to how a policy impinges on people who are in different circumstances, in particular, on people who have different income levels.

There are well-known difficulties in estimating the distributional impacts of environmental programs, individually or in total. Doing so requires very specific data showing impacts by income groups, race, or other factors. In general, environmental data have not been routinely collected by income and race. Thus, data on environmentally related issues do not typically allow the comparison of welfare impacts across socioeconomic and racial groups. Nor is it easy to estimate how program costs are distributed among these groups. This is because these welfare impacts depend on complex factors related to tax collections, consumption patterns, the availability of alternatives, and so on. Despite the difficulties, however, benefit-cost analyses should try to look as closely as possible at the way in which the aggregates are distributed through the population.

What happens when the distributional implications span generations? That is, how do we compare situations when one generation gains and another loses? Discounting at some market-based rate of interest is commonly used to express future costs and benefits in terms of present monetary value, assuming that a value received now is worth more than the same value provided at some future date. Obviously, standard discounting procedures will weight the effect on the current generation far more heavily. Thus, some critics believe that discounting results in greater resource exploitation or use of natural capital now, at the expense of future generations. Controversies in using positive discount 
rates for environmental programs with long-run impacts are not easily resolved. Some suggest that for long-run environmental projects, the appropriate discount rate is zero. But we have to be very careful here.

\begin{abstract}
A great deal of harm has been done to natural and environmental resources by using very low discount rates to evaluate development projects. With low discount rates, it is often possible to justify very disruptive public infrastructure projects because enough distant and uncertain benefits can be accumulated to outweigh the tremendous near-term costs.
\end{abstract}

\title{
Risk and Uncertainty
}

Natural resource and environmental valuation is difficult, even when there is relative certainty over prevailing economic and environmental conditions. In the "real world," analysts must confront risky outcomes in proposing environmental decisions or taking regulatory actions under conditions of uncertainty about the benefits and costs of these actions. Consequently, the notions of risk and uncertainty are related: risk relates to recurring events whose relative frequencies are known from past experience, while uncertainty relates to unique events whose probabilities can only be subjectively estimated.

Uncertainty over the outcomes of environmental actions and policies can influence the valuation of natural and environmental resources. For instance, can we say with certainty that the decontamination of DOE land will increase property values? If not, the analyst may need to introduce probability beliefs into the valuation process. The presence of risk and uncertainty affects both willingness to pay or willingness to accept compensation, with the extent of each depending on the degree of economic and environmental uncertainty confronting individuals and on their attitudes towards risk and uncertainty. Together, risk and uncertainty affect the valuation of natural and environmental resources and are commonly examined by the analyst based on extensions of the 
uncertainty affect the valuation of natural and environmental resources and are commonly examined by the analyst based on extensions of the utilitarian concept of value vis-a-vis the model of expected utility.

The first element, the degree of risk or uncertainty confronting individuals, is often considered in terms of the variance associated with random economic and/or environmental variables. For example, the valuation of decontaminated lands would very likely reflect the probability beliefs of potential buyers as to whether the land posed future human health and/or ecological risks in its alternative uses. Intuitively, the model of expected utility would predict that decontaminated land values increase as individuals are more certain that the land poses no future ecological and/or human health risks. Correspondingly, the model of expected utility predicts that a greater adversity to these risks on the part of potential buyers and/or users of the land depresses the valuation of the benefits derived from the land. Consequently, to better understand how risks and uncertainties impact natural and environmental resource valuation, it is necessary to scrutinize the methods used in the risk-assessment process and recognize how they affect the estimation of the prevailing attitudes towards risks and uncertainty.

Bearing the two related concerns in mind, the role of risk-benefit modeling remains an unresolved matter in the valuation of natural and environmental resources. The many nontrivial sampling and measurement issues that ultimately affect the outcome of the valuation process compound the difficulties in using a conceptual framework. Already, we have seen how the choice of sampling and survey instruments can influence the willingness-to-pay information obtained by contingent valuation analysts. These same considerations accompany the collection and analysis of risk-benefit data. Without this data, little if anything can be learned about the impacts of risk and uncertainty on the value of natural and environmental resources. By the same token, the risk and uncertainty faced by those who derive benefits from natural and environmental resources can only be reduced by the provision of additionall information. 
It is DOE policy that field operations provide individuals and communities with as much information as possible about the potential outcomes of their environmental policies and actions. Unfortunately, the analyst has no "hard and fast rule" or "correct way" to incorporate this information in risk-benefit models. However, the more we learn about how these risk and uncertainties manifest themselves, the more information the analyst has available to estimate the "most likely" or "least expected" values of natural and environmental resources. For instance, consider the problem of predicting the effects of certain policy changes on the occurrence of transportation accidents involving hazardous waste materials.

In any given year, we may have no transportation accidents, or one, or several; the exact number is uncertain. Yet, we may want a way to talk about the annual number of transportation-related accidents in order to weigh the impact of different types of traffic-control policies on community property values. One way of doing this is to estimate the expected number of accidents in a year and then determine the corresponding value of the damages that result. Where would we get the information to do this? If we have been collecting data over a long period of time, we might know something about actual long-run averages. In all likelihood, analysts don't have information like this, and must fall back on estimates provided by engineers, scientists, or people familiar with the problem. Based on information of this type, analysts can then develop a probability distribution of the number of hazardous waste transportation accidents and calculate the expected number of accidents in a year.

In effect, this is the average number of accidents one would experience each year over a period of time many years long. This probability parameter can then be multiplied by an estimate of resulting property damages to calculate the expected value of the damages that result from accidents involving the transportation of hazardous materials. As in this example, analysts may be able to estimate the expected number of probabilistic events and use this to calculate the impacts of increased 
risks on the expected value of natural resources. This approach is an appropriate one, provided there are reliable estimates of the probabilities of future events. Unfortunately, such estimates may not be available, particularly in those instances where we have little experience to analyze the probabilities of different outcomes with any degree of confidence. For example, consider the siting of a hazardous waste dump.

Suppose the people of a nearby community rely on a freshwater aquifer for their water supply. The analyst is asked to conduct a risk assessment to characterize the risks that the proposed waste site poses to people in the community. One part of the study is to determine the probable risks of chemicals contaminating the aquifer. This requires the expertise of engineers, hydrologists, and others who can study the physical aspects of the landfill and surrounding area. A second part of the study is to estimate the likely impacts on community health if the aquifer is contaminated. This involves using the predicted chemical levels to which people in the community would be exposed if contamination occurred and estimating the resulting health effects, for example, the expected number of increased cases of cancer. This would call on dose-response relationships that scientists have developed in analyzing this particular substance. Often, this type of information will come from laboratory studies with animals, the results of which are then extrapolated to human beings.

At this juncture of the study, economic valuation joins with the risk assessment to determine how much people value alternative situations involving differing risk levels. In our terminology, this is the estimation of people's willingness to pay to avoid the risk of damages sustained by natural resources. Clearly, the prevailing attitudes of individuals toward risk become a key determinant in the value associated with maintaining the integrity of natural resources that are damaged by human activity. To complicate matters, many natural resource and environmental risks can have negative impacts that are irreversible; they can't be undone by subsequent actions. The possibility of irreversible 
effects makes current policy decisions particularly important, inasmuch as recovery from bad decisions may be technologically impossible or prohibitively costly.

In certain circumstances, communities may have no option but to live with the consequences of current policy choices without the possibility of future rectification. Using the example of the contaminated aquifer, there would be a permanent displacement of all water uses; effectively, the water source would become economically worthless to all future generations. While there may not be a precise way to incorporate such intertemporal risks into the valuation of natural and environmental resources, the potential conflicts and/or damages that may arise from their neglect justify the analyst in taking a second look at the potential for irreversible outcomes.

\section{Margin of Error: An Order of Magnitude?}

The foregoing discussion points out that monetary valuations involving natural resources, human health, and the environment are fraught with many difficulties. These difficulties are not in the economic theory, but rather the application of relatively new valuation techniques. Many practitioners would agree that considerable progress has been made in the application of the techniques described in this handbook - an empirical claim that can only be validated through further applications and comparative analyses. However, in view of the uniqueness of circumstances surrounding each application and study site, it may be inappropriate to compare the estimated values from one study to another. For this reason, researchers have attempted to differentiate between the systematic biases in estimated values - ones which can be explained by site or sample characteristics - and their "purely random" counterparts. To illustrate, we consider the "margin of error" in value of life estimations investigated by Miller (1990). 
Referring to Miller, some 67 analyses have estimated the value of a statistical life by various valuation techniques, including the market price approach, the hedonic pricing technique, and the method of contingent valuation. In 1988 dollars, these studies yield values of a statistical life ranging from $\$ 0$ to $\$ 15$ million. Miller attempted to narrow this wide range by correcting for selected systematic biases and introducing uniform values for travel time and the discount rate to convert the risk aversion estimates into values. The potential sources of systematic biases include variations in a) the age of the population under study, b) the level of population income, c) the accuracy which people perceive the underlying risk to life, and d) the level of risk. Interestingly, once these systematic sources of bias are accounted for, the studies arrive at results which are on the same order of magnitude despite the use of different valuation methods and the circumstances surrounding site and sample data.

A thorough review of Miller's analysis is outside the scope of the present discussion. Still, it is useful to note the key results and conclusions about the various empirical estimates. First, upon adjusting for systematic biases, 47 out of the 67 values of a statistical life seemed reasonable. The reported mean and median values of this sample of studies are $\$ 2.2$ million with a standard deviation of $\$ 0.65$ million. All of the values except one survey were within 1.96 standard deviations of the mean. Table 2 shows the distribution of these values based on the underlying estimation technique in units of 0.5 standard deviations. Note that few of the results are within 0.5 standard deviations of the mean and that five of the six survey-based estimates lie above the sample mean value.

Referring to the results of his study, Miller suggests that the methodological concerns about individual studies may not be of central importance: "Although they may produce errors, the errors are not large enough to skew the values obtained." Moreover, he notes that the margin of error around the value of a statistical life is no greater than the uncertainty around many other numbers used in regulatory analysis 
and, therefore, may be used in prospective benefit-cost analysis. In this regard, the remainder of the discussion provides some closing remarks and observations on the general need for responsible use of resource valuation techniques in conducting benefit-cost analyses of regulatory standards - such as ALARA - and providing information in the environmental restoration and waste management decision-making process.

Table 2 Distribution of Values Around the Mean by Type of Study

\begin{tabular}{ccccc}
\hline Value Range & Wage-Risk & Behavior & Survey & Total \\
\hline-1.5 SD to -2 SD & 1 & 2 & -- & 3 \\
-1 to -1.5 SD & 5 & -- & 1 & 6 \\
-0.5 SD to -1 SD & 6 & 1 & -- & 7 \\
-0.5 SD to 0 & 3 & 4 & -- & 7 \\
0 to 0.5 SD & 4 & -- & 2 & 6 \\
0.5 SD to 1 SD & 6 & 2 & 2 & 10 \\
1 SD to 1.5 SD & 4 & 2 & - & 6 \\
1.5 SD to 2 SD & 1 & -- & -- & 1 \\
2 SD to 2.5 SD & -- & - & 1 & 1 \\
\hline
\end{tabular}

Source: Miller (1990), page 32 , where mean value $=\$ 2.2$ million and standard deviation $(S D)=\$ 0.65$ million (in 1980 dollars). 


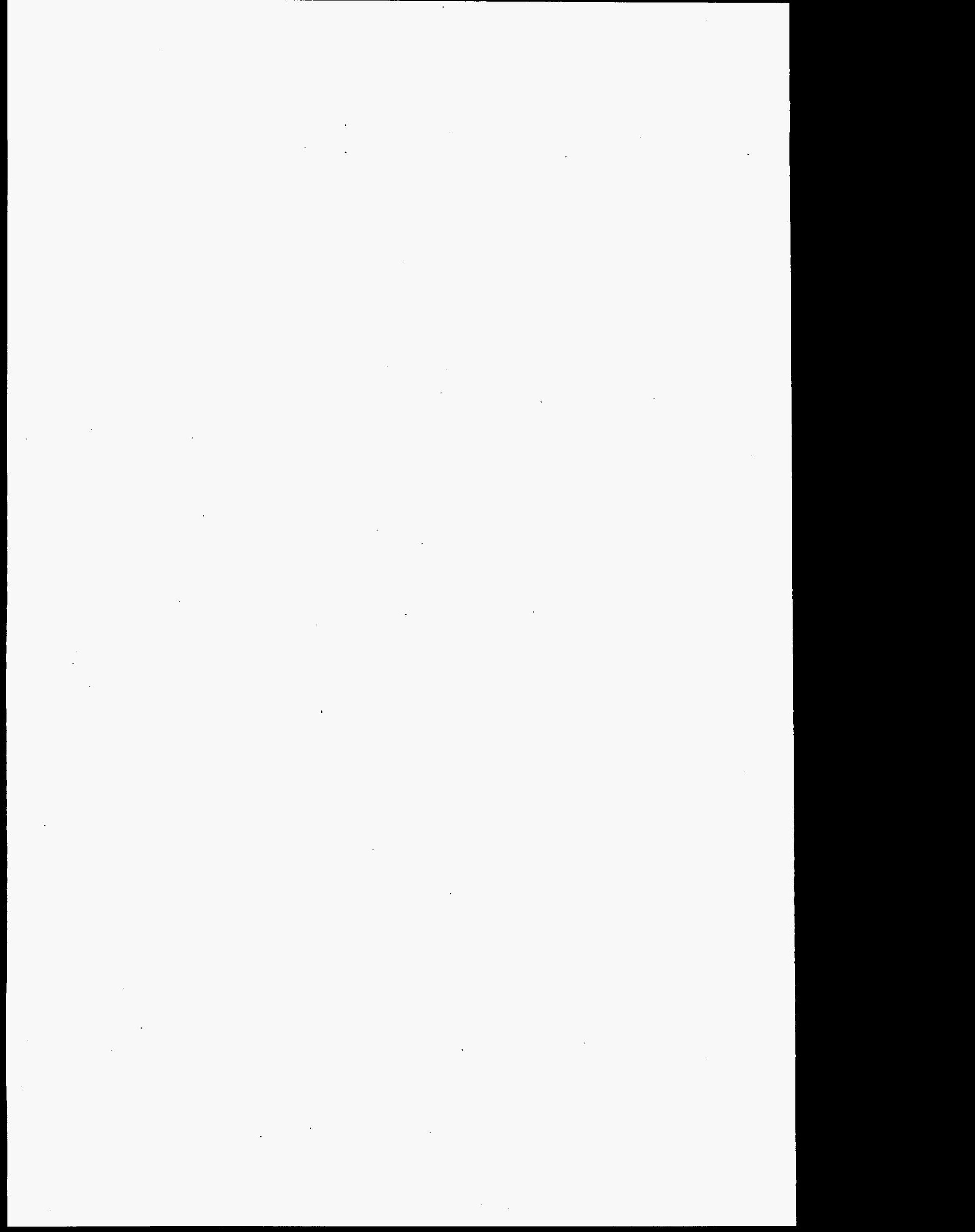




\section{Conclusions}

The application of natural resource valuation techniques is a growing science; lessons are learned as new case studies are undertaken and the benefits of additional information and experience are synthesized. Practitioners of the valuation techniques described in this handbook share the concern that dissatisfaction with technical results may lead to political interference with the methods of technical analysis. Past examples of such intervention include intervention in the benefit-cost procedures used to estimate benefits of water transportation or the choice of discount rates in federally funded water projects. The DOE must guard against making such intrusions when considering the most appropriate scientific methods to employ in the valuation of the many natural resources that are involved in environmental restoration and waste management activities around the country.

The level of technical analysis required to perform NRDA and EIS work on behalf of government agencies requires a thorough understanding of the natural resource valuation techniques described above. Responsible environmental professionals must realize that environmental restoration and waste management activities may affect many natural resources, numerous aspects of the environment, and both worker and public health and safety. A number of technical issues related to valuation concepts and techniques have been identified in the foregoing text. A short synthesis of this discussion is useful to paint a general picture of the applications and fundamental concepts that are involved.

First, the authors have suggested that monetary valuations have to cope with many problems. Foremost is that actual market prices are generally not available, so that indirect assessment procedures should be 
considered, e.g., the market price approach, the appraisal method, or identification of a suitable resource replacement cost. Second, where there is an absence of demand curves or market price information, nonmarket methods should be considered as the only viable alternative, e.g, the travel cost method, the participation/unit day value methods, hedonic pricing, and the method of contingent market valuation.

Furthermore, in the application of these techniques, the authors suggest that non-use values (bequest and existence) and option value should be counted as part of the total economic value of the underlying natural resources. For the moment, the authors conclude that ecological valuation techniques can be seen as a contribution to the more traditional valuation methods, but that their reliability is rather weak due to several shortcomings and restrictive assumptions. 


\section{Bibliography}

Adams, R. M. et al. 1989. "User Fees and Equity Issues in Public Hunting Expenditures: The Case of Ring-Necked Pheasant in Oregon." Land Economics 65(4):376-385.

American Fisheries Society. 1982. Monetary Values of Freshwater Fish and Fish-Kill Counting Guidelines, Bethesda, Maryland.

American Indian Religious Freedom Act. 1978. Public Law 95-341 as amended, 42 USC 1996 et seq.

Anderson, E., and D. Devereaux. 1986. "Testing for Two Kinds of Bias in a Contingent Valuation Survey of Anglers Using An Artificial Reef." Paper Presented at the Annual Meeting of the Eastern Economic Association, Philadelphia, Pennsylvania.

Anderson, R. J., and T. D. Crocker. 1971. "Air Pollution and Residential Property Values." Urban Studies 8:171-180.

Archaeological Resources Protection Act. 1979. Public Law 96-95 as amended, 16 USC 470aa et seq.

Bartik, T. J. 1988. "Measuring the Benefits of Amenity Improvements in Hedonic Price Models." Land Economics 64:172-183.

Berger, M. C., G. C. Blomquist, D. Kenkel, and G. S. Tolley. 1987. "Valuing Changes in Health Risks: A Comparison of Alternative Measures." Southern Economic Journal 53:967-984. 
Bergstrom, J. C., H. K. Cordell, and D. Klinko. 1989. "Recreational Benefits of Reservoir Water-Level Management." Paper Presented at the Annual USDA W-133 Meeting, San Diego, California.

Bergstrom, J. C., B. L. Dillman, and J. R. Stoll. 1985. "Public Environmental Amenity Benefits of Private Land: The Case of Prime Agricultural Land." Southern Journal of Agricultural Economics 17(1):139-149.

Bergstrom, J. C., J. R. Stoll, J. P. Titre, and V. L. Wright. 1990. "Economic Value of Wetlands-Based Recreation." Ecological Economics 2(2):129-147.

Binkley, C. S., and W.M. Hanemann. 1978. The Recreation Benefits of Water Quality Improvement: Analysis of Day Trips in an Urban Setting. Report to the U.S. Environmental Protection Agency, Washington, D.C.

Bishop, R. C., and K. J. Boyle. 1985. The Economic Value of Illinois Beach State Nature Preserve. Final Report to Illinois Department of Conservation, Heberlein Baumgartner Research Services, Madison, Wisconsin.

Bishop, R. C., and K. Boyle. 1986. "The Economic Value of Endangered Species of Wildlife." In Transactions of the 51 st North American Wildlife and Natural Resources Conference.

Bishop, R. C., and K. J. Boyle. 1987. "Valuing Wildlife in BenefitCost Analysis: A Case Study Involving Endangered Species." Water Resources Research 23(5):943-950.

Bishop, R. C., K. J. Boyle, and M. P. Welsh. 1987. "Toward Total Economic Valuation of Great Lakes Fishery Resources." Transactions of the American Fisheries Society 116:352-373. 
Bockstael, N. E., W. M. Hanemann, and C. L. Kling. 1987.

"Modeling Recreational Demand in a Multiple Site Framework." Water Resources Research 23:951-960.

Bockstael, N. E., W. M. Hanemann, and C. L. Kling. 1987. "Estimating the Value of Water Quality Improvements in a Recreational Demand Framework." Water Resources Research 23:951-960.

Boyle, K. J., and R. C. Bishop. 1979. "Toward the Total Valuation of the Great Lakes Fishery Resources." Water Resources Research 5:943-990.

Boyle, K. J., S. D. Reiling, and M. L. Phillips. 1990. "Species Substitution and Questions Sequencing in Contingent Valuation Surveys Evaluating the Hunting of Several Types of Wildlife." Leisure Science 12:103-118.

Braden, J., C. Kolstad, R. Woock, and J. Machado. 1992. "The Demand for Synthetic Fuels: Contingent Valuation of QualityDifferentiated Factors of Production." Paper Presented at the Annual Meeting of the European Association of Environmental and Resource Economists, Cracow, Poland.

Brooks, R. 1991. Warm Water Fishing in Montana: A Contingent Valuation Assessment of Angler Attitudes and Economic Benefits for Selected Waters Statewide. Report Prepared for State of Montana Department of Fish, Wildlife and Parks, Helena, Montana.

Brookshire, D. S., R. C. d'Arge, W. D. Schulze, and M. A. Thayer. 1979. "Experiments in Valuing Non-Marketed Goods: A Case Study of Alternative Benefit Measures of Air Pollution Control in the South Coast Air Basin of Southern California." Methods Development for Assessing Tradeoffs in Environmental Management, Vol. 2. National Technical Information Service, Washington, D.C. 
Brookshire, D. S., L. S. Eubanks, and A. Randall. 1978. "Valuing Wildlife Resources: An Experiment." In 43rd Transactions of the North American Wildlife Conference, Wildlife Management Institute, Washington, D.C.

Brookshire, D. S., L. S. Eubanks, and A. Randall. 1983. "Estimating Option Prices and Existence Values for Wildlife Resources." Land Economics 59:1-15.

Carson, R. T., W. M. Hanemann, and D. Steinberg. 1990. "A Discrete Choice Contingent Valuation Estimate of the Value of Kenai King Salmon." Journal of Behavioral Economics 19(1):53-68.

Carson, R. T., R. C. Mitchell, and P. A. Ruud. 1990. "Valuing Air Quality Improvements: Simulating a Hedonic Pricing Equation in the Context of a Contingent Valuation Scenario." In Visibility and Fine Particles, C. V. Mathai, ed., Air and Waste Management Association, Pittsburgh, Pennsylvania.

Carson, R. T., and P. A. Ruud. 1991. Grand Canyon Visibility Benefits Calculations. Report to W. E. Balson, Decision Focus, Los Altos, California.

Chestnut, L. G., et. al. 1988. Heart Disease Patients' Averting Behavior; Costs of Illness and Willingness to Pay to Avoid Angina Episodes. Final Report (EPA-230-10-88-042), Cooperative Agreement No. CR-812826, Office of Policy Analysis, U.S. Environmental Protection Agency, Washington, D.C.

Chestnut, L. G., L. R. Keller, W. Lambert, and R. D. Rowe. 1992. 'Measuring Heart Patients' Willingness to Pay for Changes in Angina Symptoms: Some Methodological Implications." Graduate School of Management, University of California, Irvine, California. 
Chestnut, L. G., and R. D. Rowe. 1990. "Review and Response to: Development and Design of a Contingent Value Survey for Measuring the Public's Value for Visibility Improvements at the Grand Canyon National Park." Draft Report Prepared by RCG/Hagler, Bailly, Inc. for Economic Analysis Branch, Office of Air Quality Planning and Standards, U.S. EPA, Boulder, Colorado.

Chestnut, L. G., and R. D. Rowe. 1991. Economic Changes in Visibility: A State of the Science Assessment for NAPAP, SOS 27 for the National Acidic Precipitation Assessment Program.

Clawson, M. 1959. Methods of Measuring the Demand for and Value of Outdoor Recreation. Resources for the Future, Reprint No. 10, Washington, D.C.

Clawson, M., and J. L. Knetsch. 1966. Economics of Outdoor Recreation. Johns Hopkins University Press, Baltimore, Maryland.

Clean Water Act (Federal Water Pollution Control Act). 1948. 62 Stat 1155 as amended, 33 USC 1251 et seq.

Clean Air Act. 1986. Public Law 88-206 as amended, 42 USC 7401 et seq.

Cocheba, D. J., and W. A. Langford. 1978. "Wildlife Valuation: The Collective Good Aspect of Hunting." Land Economics 54 (4): 490-504.

Comprehensive Environmental Response, Compensation, and Liability Act. 1980. Public Law 96-510 as amended, 42 USC 9601 et seq.

Crocker, T. D. 1985. "On the Value of the Condition of a Forest Stock." Land Economics 61(3):244-254. 
Desvousges, W. H., M. C. Naughton, and G. R. Parsons. 1992.

"Benefit Transfer: Conceptual Problems in Estimating Water Quality Benefits Using Existing Studies." Water Resources Research 28(3)

[Special Section: Problems and Issues in the Validity of Benefit Transfer Methodologies.]

Desvousges, W. H., V. K. Smith, and M. P. McGivney. 1983. A Comparison of Alternative Approaches for Estimating Recreation and Related Benefits of Water Quality Improvements. EPA

Report 230-05-83-001, U.S. Environmental Protection Agency, Office of Policy Analysis, Washington, D.C.

Diamond, D. B., Jr., 1980. "The Relationship Between Amenities and Urban Land Prices." Land Economics 56(1):21-32.

Diamond, D. B., Jr., and G. Tolley, (ed.) 1982. The Economics of Urban Amenities. Academic Press, New York.

Doane, M. J., R. S. Hartman, and C. K. Woo. 1988. "Household's Perceived Value of Service Reliability: An Analysis of Contingent Valuation Data." Energy Journal 9:135-150.

Donnelly, D. M., J. B. Loomis, C. F. Sorg, and L. J. Nelson. 1985. "Net Economic Value of Recreational Steelhead Fishing in Idaho." U.S. Forest Service Bulletin RM-9, Rocky Mountain Forest and Range Experiment Station, Fort Collins, Colorado.

Dragun, A. K. 1991. "An Economic Study of Commercial and Recreational Fishing Conflicts in Port Philip Bay and Western Port, Victoria, Australia." Report Prepared for the Victorian Department of Conservation and Environment, Department of Legal Studies, La Trobe University. 
Duffield, J. W. 1988. The Net Economic Value of Elk Hunting in Montana, Report to Montana Department of Fish, Wildlife, and Parks, Helena, Montana.

Duffield, J. W. 1991. "Existence and Nonconsumptive Values for Wildlife: Application to Wolf Recovery in Yellowstone National Park." Paper Presented at the Annual USDA W-133 Meeting, Monterey, California.

Duffield, J. W. 1991. "Total Valuation of Wildlife and Fishery Resources: Applications in the Northern Rockies." Paper Presented at the National Conference on the Economic Value of Wilderness, U.S. Forest Service and Society of American Foresters, Jackson Hole, Wyoming.

Duffield, J. W., and C. Neher. 1991. Montana Waterfowl Hunting: A Contingent Valuation Assessment of Economic Benefits and Hunter Attitudes. Report to Montana Department of Fish, Wildlife, and Parks, Helena, Montana.

Edwards, S. F. 1988. "Option Prices for Groundwater Protection." Journal of Environmental Economics and Management 15(4):475-487.

Endangered Species Act. 1973. Public Law 93-205 as amended, 16 USC 1531 et seq.

Environmental Science and Technology. 1980. Groundwater Strategies, Vol. 14, pp. 1030-35.

Executive Order 11988, "Floodplain Management." May 24, 1977. 42 FR 26951.

Executive Order 11990, "Protection of Wetlands." May 24, 1977. 42 FR 26961. 
Executive Order 12580, "Superfund Implementation." January 23, 1987. 52 FR 2923.

Freeman, A. M., III. 1971. "Air Pollution and Property Values: A Methodological Comment." Review of Economics and Statistics 53:415-416.

Freeman, A. M., III. 1974. "Air Pollution and Property Values: A Further Comment." Review of Economics and Statistics 56:554-556.

Freeman, A. M., III. 1974. "On Estimating Air Pollution Control Benefits from Land Value Studies." Journal of Environmental Economics and Management 1:277-288.

Guidance Manual for Minimizing Pollution from Waste Disposal Sites, EPA 600/2-78-142, U.S. Environmental Protection Agency, Washington, D.C.

Hoehn, J. P. 1987. "Contingent Valuation in Fisheries Management: The Design of Satisfactory Contingent Valuation Formats." Transactions of the American Fisheries Society 116:412-419.

Hoehn, J. P., and G. Fishelson. 1987. "Measuring the Economic Impact of Visibility." Staff Paper No. 87-21, Department of Agricultural Economics, Michigan State University.

Huppert, D. D. 1989. "Measuring the Value of Fish to Anglers: Application to Central California Anadromous Species." Marine Resource Economics 6:89-107.

Interagency Land Acquisition Conference. 1991. Uniform Appraisal Standards for Federal Land Acquisitions. Government Printing Office, Washington, D.C. 
Kneese, A. V. 1984. Measuring the Benefits of Clean Air and Water. Resources for the Future, Inc., Washington, D.C.

Kopp, R. J., and V. K. Smith. 1992. "Eagle Mine and Idarado." In Natural Resource Damage: Law and Economics, K. M. Ward and J. W. Duffield (ed.), John Wiley and Sons, Inc., New York, pp. 365-388.

Loehman, E. T., and D. Boldt. 1988. "Specification of Willingness to Pay Benefit Functions for Air Quality: A Comparison of Theory and Empirical Measurement." Mimeo, Purdue University, Indiana.

Loomis, J., and Anderson, P. 1992. Idaho v. Southern Refrigerated in Natural Resource Damages: Law and Economics, Ward and Duffield (ed.), John Wiley and Sons, Inc., New York.

Loomis, J. B. 1987. An Economic Evaluation of Public Trust Resources of Mono Lake. Institute of Ecology Report \#30, College of Agricultural and Environmental Sciences, University of California, Davis, California.

Loomis, J. B., and J. Cooper. 1988. The Net Economic Value of Antelope Hunting in Montana. Report Prepared for Montana Department of Fish, Wildlife, and Parks, Helena, Montana.

Loomis, J. B., J. Cooper, and S. Allen. 1988. The Montana Elk Hunting Experience: A Contingent Valuation Assessment of Economic Benefits to Hunters. Report Prepared for Montana Department of Fish, Wildlife, and Parks, Helena, Montana.

Loomis, J. B., M. Creed, and J. C. Cooper. 1989. Economic Benefits of Deer in California: Hunting and Viewing Values. Institute of Ecology Report \#3, University of California, Davis, California. 
Loomis, J., and Anderson, P. 1992. "Idaho v. Southern Refrigerator." In Natural Resource Damages: Law and Economics, Ward, K. M. and Duffield, W. J. (ed.), Wiley Law Publications, New York, pp. 389-414.

Luken, R. A., F. R. Johnson, and V. Kibler. 1992. "Benefits and Costs of Pulp and Paper Effluent Controls Under the Clean Water Act." Water Resources Research 28(3):665-667.

Mathews, S. B., and G. M. Brown. 1970. Economic Evaluation of the 1967 Sport Salmon Fisheries of Washington, Technical Report No. 2, Washington Department of Fisheries, Olympia, Washington.

McClelland, G. H., et al. 1991. Valuing Eastern Visibility: A Field Test of the Contingent Valuation Method-Innovative Approaches for Valuing Perceived Environmental Quality. U.S. Environmental Protection Agency Cooperative Agreement \#CR-815183-01-3, U.S. Environmental Protection Agency, Washington, D.C.

Meyer, P. A. 1978. Updated Estimates for Recreation and Preservation Values Associated with the Salmon and Steelhead of the Fraser River. Environment Canada, Vancouver, BC.

Meyer, P. A. 1979. "A Publicly Vested Values for Fish and Wildlife: Criteria in Economic Theory and Interface with the Law." Land Economics 55(2):223-235.

Meyer, P. A. 1980. Recreational/Aesthetic Values Associated with Selected Groupings of Fish and Wildlife in California's Central Valley. Report to the U.S. Fish and Wildlife Service, Sacramento, California.

Meyer, P. A. 1987. The Value of King Salmon, Harbor Seals and Wetlands of San Francisco Bay. The Bay Institute of San Francisco, San Francisco, California. 
Milon, J. W. 1986. "Economic Evaluation of Artificial Habitat for Fisheries: Progress and Challenges." Discussion paper, Food and Resource Economics Department, University of Florida, Gainesville, Florida.

Mitchell, R. C. and R. T. Carson. 1988. Towards a Methodology for Using Contingent Valuation to Value Air Visibility Benefits. Draft Report to the Electric Power Institute, Resources for the Future, Washington, D.C.

Mitchell, R. C., R. T. Carson, and P. A. Ruud. 1989. Cincinnati Visibility Valuation Study: Pilot Study Findings. Report submitted to the Electric Power Research Institute, Resources for the Future, Washington, D.C.

Morey, E. R., et al. 1991. "A Discrete Choice Model of Recreational Participation, Site Choice, and Activity Valuation When Complete Trip Data Is Not Available." Journal of Environmental Economics and Management 20:181-201.

Nachtman, S. C. 1983. Valuation of the Maroon Valley Mass Transit System for Recreational Visitors. Thesis, Colorado State University, Colorado Springs.

National Environmental Policy Act. 1969. Public Law 91-190, 42 USC 4321 et seq.

National Historic Preservation Act. 1966. Public Law 89-665 as amended, 16 USC 470 et seq.

Olsen, D., J. Richards, and D. R. Scott. 1991. "Existence and Sport Values for Doubling the Size of Columbia River Basin Salmon and Steelhead Runs." Rivers 2(1):44-56. 
Palmquist, R. B. 1983. "Estimating the Demand for Air Quality from Property Values Studies: Further Results." Working Paper, North Carolina State University, Raleigh, North Carolina.

Palmquist, R. B., and L. E. Danielson. 1989. "A Hedonic Study of the Effects of Erosion Control and Drainage on Farmland Values." American Journal of Agricultural Economics 71:55-62.

Polinsky, A. M., and S. Shavell. 1975. "The Air Pollution and Property Value Debate." Review of Economics and Statistics 57(1):100-104.

Polinsky, A. M., and S. Shavell. 1976. "Amenities and Property Values in a Model of an Urban Area." Journal of Public Economics 5:119-129.

Randall, A. 1979. "The Economic Value of Atmospheric Visibility." In Proceedings of the Workshop on Visibility Values, U.S. Forestry Service Technical Report WO-18.

Randall, A., G. C. Blomquist, J. P. Hoehn, and J. R. Stoll. 1985. National Aggregate Benefits of Air and Water Pollution Control. Cooperative Agreement CR811056-01-0, Interim report to the U.S. Environmental Protection Agency, University of Kentucky, Lexington, Kentucky.

RCG/Hagler, Bailly, Inc. 1986. Value-Based Planning for Electric Utilities. Prepared for California Energy Commission, Boulder, Colorado.

RCG/Hagler, Bailly, Inc. 1988. Optimal Selection of Reliability Standards in Practice and Theory. Prepared for Electric Power Research Institute, Boulder, Colorado. 
RCG/Hagler, Bailly, Inc. 1989. Customer Value of Service Reliability: Volume 1: Summary. Prepared for Southern California Edison Company, Rosemead, California, Boulder, Colorado.

RCG/Hagler, Bailly, Inc. 1989. Customer Value of Service Reliability: Volume 2: Residential Customers. Prepared for Southern California Edison Company, Rosemead, California, Boulder, Colorado.

RCG/Hagler, Bailly, Inc. 1989. Customer Value of Service Reliability: Volume 3: Commercial and Industrial Customers. Final Report 1989-6012, prepared for Southern California Edison Company, Rosemead, California, Boulder, Colorado.

RCG/Hagler, Bailly, Inc. 1989. Customer Value of Service Reliability: Volume 4: Methodology. Final Report, prepared for Southern California Edison Company, Rosemead, California; Boulder, Colorado.

RCG/Hagler, Bailly, Inc. 1990. Cost-Benefit Analysis of Power System Reliability: Determination of Interruption Costs Volume 2: Measurement of Interruption Costs for the Bonneville Power Administration. Final Report Project 2878-1, Report Number EL-6791, prepared for the Bonneville Power Administration and Electric Power Research Institute, Palo Alto, California.

RCG/Hagler, Bailly, Inc. 1990. Cost-Benefit Analysis of Power System Reliability: Determination of Interruption Costs Volume 3: Measurement of Interruption Costs for a Major Southeast Utility. Final Report Project 2878-1, Report Number EL-6791, prepared for the Bonneville Power Administration and Electric Power Research Institute, Palo Alto, California.

RCG/Hagler, Bailly, Inc. 1991. Economic Penalties Including Customer Costs for Loss of Service Continuity. CEA No. SD-2730, Boulder, Colorado. 
RCG/Hagler, Bailly, Inc. 1991. Survey of Customer Outage Costs. 2 vol. Prepared for Southern Company Services, Inc., Boulder, Colorado.

Rowe, R. D., R. C. D'Arge, and D. S. Brookshire. 1980. "An Experiment on the Economic Value of Visibility." Journal of Environmental Economics and Management, 1-19.

Rowe, R. D., and L. G. Chestnut. 1986. "Valuing Changes in Morbidity WTP versus COI Measures." Paper presented at the American Economic Annual Meetings, Dallas, Texas.

Sanghvi, A. P. 1990. Cost-Benefit Analysis of Power System Reliability: Determination of Interruption Costs Volume 1: Measurement Methods and Potential Applications in Reliability Cost-Benefit Analysis. Final Report Project 2878-1, Report Number EL-6791, prepared by RCG/Hagler, Bailly, Inc., for the Electric Power Research Institute, Palo Alto, California, Washington, D.C.

Schulze, W. D., et al. 1983. "The Economic Benefits of Preserving Visibility in the National Parklands of the Southwest." Natural Resources Journal 23:149-173.

Schulze, W. D., D. S. Brookshire, and M. A. Thayer. 1981. "National Parks and Beauty: A Test of Existence Values." Paper presented at the American Economic Association Annual Meeting, Washington, D.C.

Schulze, W. D., D. S. Brookshire, E. G. Walter, and K. Kelley. 1981. "The Benefits of Preserving Visibility in the National Parklands of the Southwest, Report to the U.S. Environmental Protection Agency." In Methods Development for Air Pollution Control Benefits Assessment. Resource \& Environmental Economics Lab, University of Wyoming, Laramie, Wyoming. 
Schulze, W. D., T. Crocker, B-D. Shaul, and A. Kneese. 1979. Methods Development for Assessing Air Pollution Control Benefits. 5 vols. Report to the U.S. Environmental Protection Agency, Resource \& Environmental Economic Lab, University of Wyoming, Laramie, Wyoming.

Scott, M., G. R. Bilyard, S. O. Link, P. F. Ricci, H. E. Sealy, C. A. Ulibarri, and H. E. Westerdahl. 1997. "The Valuation of Ecological Resources and Functions." Environmental Management (forthcoming).

Shechter, M. 1985. "Economic Aspects in the Investigation of Groundwater Contamination Episodes." Ground Water, Volume 23, Number 2, U.S. Environmental Protection Agency.

Shechter, M., and M. Zeidner. 1990. "Anxiety: Towards a Decision Theoretic Perspective." The British Journal of Mathematical and Statistical Psychology 43:15-28.

Smith, V. K., and W. H. Desvousges. 1985. "The Generalized Travel Cost Model and Water Quality Benefits: A Reconsideration." Southern Economic Journal 52:371-381.

Smith, V. K. and W. H. Desvousges. 1986. Measuring Water Quality Benefits. Kluwer-Nijhoff Publishing, Boston, Massachusetts.

Smith, V. K. and Y. Kaoru. 1990. "Signals or Noise? Explaining the Variation in Recreation Benefit Estimates." American Journal of Agricultural Economics 72:419-433.

Smith, V. K., R. B. Palmquist and P. Jackus. 1989. "A NonParametric Hedonic Travel Cost Model for Valuing Estuarine Quality." Working paper, North Carolina State University, Raleigh, North Carolina. 
Smith, V. K., and Y. S. Eom. 1992. "Linking Revealed and Stated Preferences Data in Describing Consumer Responses to Risk: Pesticide Residues on Food." Presented at the Annual Meeting of the Association of Environmental and Resource Economists.

Sorg, C. F., and J. B. Loomis. 1984. Empirical Estimates of Amenity Forest Values: A Comparative Review. General Technical Report RM-107, Rocky Mountain Forest and Range Experiment Station, U.S. Forest Service, Fort Collins, Colorado.

Sorg, C. F., and L. J. Nelson. 1986. Net Economic Value of Elk Hunting in Idaho. U.S. Forest Service Resource Bulletin RM-12, Rocky Mountain Forest and Range Experiment Station, U.S. Forest Service, Fort Collins, Colorado.

Stoll, J. R. 1980. The Valuation of Hunting Related Amenities: A Conceptual and Empirical Approach. Dissertation, DAI, Vol. 41, 4783, University of Kentucky.

Stoll, J., and L. Johnson. 1984. "Concepts of Value, Non-Market Valuation, and the Case of the Whooping Crane." Transactions of the North American Wildlife and Natural Resources Conference 49.

Ulibarri, C. A. and S. Ghosh. 1995. "Benefit-Transfer Valuation of Ecological Resources." Pacific Northwest National Laboratory, Richland, Washington.

United States Water Resources Research Council. 1983. Economic and Environmental Principles and Guidelines for Water and Related Land Resources Implementation Studies. United States Government Printing Office, Washington, D.C. 
vanRavensway, E. O., and J. P. Hoehn. 1991. "Contingent Valuation and Food Safety: The Case of Pesticide Residues in Food." Staff Paper No. 91-13, Department of Agricultural Economics, Michigan State University.

vanRavensway, E. O., and J. P. Hoehn. 1991. "Consumer Willingness to Pay for Reducing Pesticide Residues in Fresh Produce." Staff Paper No. 91-18, Department of Agricultural Economics, Michigan State University.

Vaughn, W. J., and C. S. Russell. 1982. "Valuing a Fishing Day: An Application of a Systematic Varying Parameter Model." Land Economics 58:450-630.

Viscusi, W. K., W. A. Magat, and J. Huber. 1989. Pricing Environmental Health Risks: Survey Assessments of Risk-Risk and Risk-Dollars Trade-Off. Research report to U.S. Environmental Protection Agency, Washington, D.C.

Viscusi, W. Kip. 1990. "The Value of Life: Has Voodoo Economics Come to the Courts?" Journal of Forensic Economics 3(3):1-15.

Walsh, R. G. 1991. "Empirical Evidence on Benefits of Protecting Old Growth Forests and the Spotted Owl." Appendix B in Economic Analysis of Designation of Critical Habitat for the Northern Spotted Owl, U.S. Department of the Interior, Fish and Wildlife Service, Washington, D.C.

Walsh, R. G., R. D. Bjonback, R. A. Aiken and D. H. Rosenthal. 1990. "Estimating the Public Benefits of Protecting Forest Quality." Journal of Environmental Management 30(2):1975-1989.

Walsh, R. G., and L. O. Gilliam. 1982. "Benefits of Wilderness Expansion with Excess Demand for Indian Peaks." Western Journal of Agricultural Economics 7:1-12. 
Walsh, R. G., D. M. Johnson and J. R. McKean. 1988. Review of Outdoor Recreation Research Economic Demand Studies with Nonmarket Benefits Estimates: 1968-1988. Technical Report No. 54, Colorado Water Resources Research Institute, Colorado State University, Fort Collins, Colorado.

Walsh, R. G., D. M. Johnson, and J. R. McKean. 1990. "Non-Market Values from Two Decades of Research on Recreational Demand." In Advances in Applied Microeconomics, A. N. Link and V. K. Smith, (ed.), vol. 5, pp.167-193, JAI Press, Greenwich.

Walsh, R. G., D. M. Johnson, and J. R. McKean. 1992. "Benefit Transfer of Outdoor Recreation Demand Studies, 1968-1988. "Water Resources Research 28 (3) [Special Section: Problems and Issues in the Validity of Benefit Transfer Methodologies.]

Walsh, R. G., J. B. Loomis and R. A. Gillman. 1984. "Valuing Option, Existence and Bequest Demands for Wilderness." Land Economics 60:14-29.

Ward, K. M., and J. W. Duffield. 1992. Natural Resource Damages: Law and Economics. Wiley Law Publications, New York.

Woo, C-K., and R. L. Pupp. 1992. "Costs of Service Disruptions to Electricity Consumers." Energy 17:109-126. 


\section{Appendix A}

\section{Economics Glossary}




\section{Appendix A}

\section{Economics Glossary}

benefit-cost analysis - a technique to compare the relative economic efficiency of different states of the world usually brought about by undertaking projects or policies. A comparison is made between gross benefits of a project or policy and the opportunity costs of the action. Benefits and costs are measured as changes in consumer and producer surpluses accruing to individuals in society.

consumer surplus - a money measure of an individual's or group's welfare from consumption of a good or service or the existence of a particular state of the world. This surplus is the difference between the maximum the individual is willing to pay for consumption of the good and the amount that has to be paid.

consumptive use value - values held for the use of natural resource services which involve the physical use of the environment (e.g., fishing, duck hunting).

contingent valuation - a methodology to determine money measures of change in welfare by describing a hypothetical situation to respondents and eliciting how much they would be willing to pay either to obtain or to avoid the situation. 
demand - in economics, the usual inverse relationship between quantity consumed (or otherwise used or even preserved) and a person's maximum willingness to pay for incremental increases in quantity. Market prices often (but not always) reveal the increments of willingness to pay. Other factors influencing willingness to pay include income, prices of substitutes, and, in recreational fishing, catch rate. Unlike planning, where demand refers to the size of the quantity variable, economic demand is a behavioral relationship.

discount rate - a measure of the opportunity cost of not having immediate access to resources. Traditionally, discount rates may reflect the interest rate on savings accounts, financial portfolios, or bonds. Discount rates may also reflect other social, psychological, and intertemporal concerns.

discounting - a procedure to use when comparing value streams (benefits or costs) occurring in different magnitudes at different dates in the future. The procedure "discounts" future values in order to obtain the present value of the stream.

environmental valuation - procedures for valuing changes in environmental goods and services, whether or not they are traded in markets, by measuring the changes in the producer and consumer surpluses associated with these environmental goods.

existence value - see nonuse value.

gross domestic product - aggregate annual output of the economy before deducting the value of the assets of the economy that have been used up or depreciated in the production process during the year. Gross domestic product provides a summary measure of the nation's overall economic performance. 
hedonic method - a methodology for estimating the relationship between the price of a good (e.g., housing) and the characteristics of the good (e.g., number of bedrooms, air quality, proximity to amenities, etc.). It can sometimes be used to value changes in environmental characteristics.

input-output model - a methodology that models the linkages between input supplies, outputs, and households in a regional economy that can be used to predict the impact of changes on economic activity within the region (e.g., industry revenues and household incomes).

market benefits - benefits from goods or services bought and sold in normal commerce so that there is a revealed price that reflects consumers' willingness to pay for the quantity offered and suppliers' marginal production costs.

nonconsumptive use values - values held for the use of natural resource services that do not imply actual harvest of any resource (e.g., canoeing, swimming, bird-watching).

nonmarket benefits - benefits that accrue to individuals for goods, services, experiences, or states of nature that are not normally traded in commerce.

nonuse value (see also use value) - the value of knowing that something exists in a particular state even though there is no sensory contact with the resource. Nonuse values are often referred to as existence value, intrinsic value, or preservation or bequest value. A recent term of art is passive use value.

opportunity cost - the highest value a productive resource, such as labor, capital, land or a natural resource, could return if placed in its best alternative use.

passive use value - see nonuse value. 
producer surplus - total revenue minus the opportunity cost of production, including the opportunity costs of the entrepreneur's skills, labor, capital, and ownership of natural resources.

random utility model - an extension of the travel cost method that explicitly considers individual's participation decisions and the selection among alternative recreation sites.

supply - schedule of the quantities of goods and services that a business is willing to sell at various prices. Other factors that affect supply include input prices.

travel cost method - a methodology that relies on travel-related costs as a surrogate for price in a nonmarket situation in order to estimate demand and money measures of willingness to pay.

use value - value derived from either the consumption of a good or the utilization of a service or that otherwise involves some sensory contact with the resource. For example, whale-watching is not consumptive, but involves visual contact with the whales.

value - what one is willing to give up in order to obtain a good, service, experience, or state of nature. Economists try to measure this in dollars.

welfare economics - a field of inquiry within the broad scope of economics that is concerned with money measures of individual and social well-being, particularly in changes in well-being due to implementation of public policies.

willingness to pay - the maximum sum of money an individual would be willing to pay rather than do without an increase in some good such as an environmental amenity. This sum is the amount of money that would make the individual indifferent to either a) paying for and having the improvement or b) forgoing the improvement while keeping the money to spend on other things. 
willingness to accept - the minimum sum of money an individual would require to voluntarily forgo an improvement that otherwise would be experienced. It is the amount that would make a person indifferent to either having the improvement and forgoing the improvement while getting extra money. 


\section{Appendix B}

\section{Regulatory Glossary}




\section{Appendix B}

\section{Regulatory Glossary}

This appendix summarizes important state and federal environmental protection statues under which U.S. Department of Energy (DOE) field operations are run and which can impact the value of the environment and natural resources.

National Environmental Policy Act (NEPA) - designed to lessen or eliminate damages to the environment and to protect natural resources. It requires that the impacts to the environment of any major federal project be carefully reviewed and reported in environmental impact statements, environmental assessments, or other NEPA-generated documents (Arbuckle et al. 1989).

Clean Air Act (CAA) - designed to protect public health by establishing national air quality standards. Although the primary regulatory control for the CAA rests with state and local governments, the CAA gave the U.S. Environmental Protection Agency (EPA) the authority to establish minimum air quality standards and outline air pollution control measures for state and local governments to achieve. 
Clean Water Act (CWA) - provides the basic framework for federal water pollution control regulation. As stated in Section 101 of the Act, the CWA is designed to "restore and maintain the chemical, physical, and biological integrity of the nation's waters." The five main elements of the act include a permit program, national effluent standards for specific industries, water quality standards, provisions for occurrences such as toxic and oil spills, and a grant program for construction of publicly owned treatment facilities (Arbuckle et al. 1989).

Resource Conservation and Recovery Act (RCRA) - establishes regulatory standards that are imposed on the generators and transporters of hazardous materials. It also provides regulatory standards for the treatment, storage, and disposal of hazardous materials (Arbuckle et al. 1989).

Comprehensive Environmental Response, Compensation, and Liability Act (CERCLA) - establishes a program that provides funding and enforcement authority for the cleanup of sites contaminated by hazardous substances. The Superfund Amendments and Reauthorization Act (SARA) broadened the scope of CERCLA to include provisions for federal facilities. The CERCLA joins with RCRA to provide complete regulatory coverage of hazardous waste disposal. While RCRA focuses on a "cradle-to-grave" approach to present hazardous waste activities, CERCLA establishes a response program to past hazardous waste activities (Arbuckle et al. 1989).

Toxic Substance Control Act (TSCA) - gives the EPA authority to require testing of substances that enter the environment, as well as the authority to regulate those substances. This regulation supplements the Clean Air Act and Clean Water Act regulatory control over toxic substances (Arbuckle et al. 1989). 
Endangered Species Act - provides for conservation, restoration, propagation, and protection of species that have been declared threatened or endangered. The Act requires all federal agencies to conserve endangered wildlife and provides for the listing of critical habitats essential to species survival.

American Indian Religious Freedom Act - requires that no federal agency interfere with the right of any Native American to exercise their traditional religious beliefs. This Act also states that the Native American's right to worship includes access to religious sites and possession and use of traditional religious objects.

National Historic Preservation Act - designed to protect, restore, and reconstruct sites, buildings, and objects that are significant to American history or culture. It also requires the study of impacts to any historical or archaeological sites by any federal activity.

Archaeological Resources Protection Act - designed to protect and regulate the use of archaeological resources on federal and Native American lands by prohibiting excavation or removal of resources without a permit.

Executive Order 11988 on Floodplain Management - designed to lessen or eliminate impacts to floodplains by regulating floodplain use and modification.

Executive Order 11990 on Protection of Wetlands - designed to lessen or eliminate damages to wetland areas by preventing new construction in wetland areas and by requiring any damages to be mitigated. 
Executive Order 12866 on Regulatory Planning and Review -

designed to reform and make more efficient the regulatory process. The objectives are to enhance planning and coordination with respect to both new and existing regulations, to reaffirm the primacy of federal agencies in the regulatory decision-making process, to restore the integrity and legitimacy of regulatory review and oversight, and to make the process more accessible and open to the public. 